Article

\title{
Significance of Viral Activity for Regulating Heterotrophic Prokaryote Community Dynamics along a Meridional Gradient of Stratification in the Northeast Atlantic Ocean
}

\author{
Kristina D. A. Mojica ${ }^{1,2, *(1)}$ and Corina P. D. Brussaard ${ }^{1}(\mathbb{C}$ \\ 1 Department of Biological Oceanography, Royal Netherlands Institute for Sea Research (NIOZ), P.O. Box 59, \\ 1790 AB Den Burg, Texel, The Netherlands; Corina.Brussaard@nioz.nl \\ 2 Division of Marine Science, School of Ocean Science and Engineering, The University of Southern \\ Mississippi, Stennis Space Center, MS 39529, USA \\ * Correspondence: Kristina.Mojica@usm.edu; Tel.: +1-22-8688-3003
}

Received: 25 September 2020; Accepted: 9 November 2020; Published: 12 November 2020

\begin{abstract}
How microbial populations interact influences the availability and flux of organic carbon in the ocean. Understanding how these interactions vary over broad spatial scales is therefore a fundamental aim of microbial oceanography. In this study, we assessed variations in the abundances, production, virus and grazing induced mortality of heterotrophic prokaryotes during summer along a meridional gradient in stratification in the North Atlantic Ocean. Heterotrophic prokaryote abundance and activity varied with phytoplankton biomass, while the relative distribution of prokaryotic subpopulations (ratio of high nucleic acid fluorescent (HNA) and low nucleic acid fluorescent (LNA) cells) was significantly correlated to phytoplankton mortality mode (i.e., viral lysis to grazing rate ratio). Virus-mediate morality was the primary loss process regulating the heterotrophic prokaryotic communities (average $55 \%$ of the total mortality), which may be attributed to the strong top-down regulation of the bacterivorous protozoans. Host availability, encounter rate, and HNA:LNA were important factors regulating viral dynamics. Conversely, the abundance and activity of bacterivorous protozoans were largely regulated by temperature and turbulence. The ratio of total microbial mediated mortality to total available prokaryote carbon reveals that over the latitudinal gradient the heterotrophic prokaryote community gradually moved from a near steady state system regulated by high turnover in subtropical region to net heterotrophic production in the temperate region.
\end{abstract}

Keywords: bacterial production; marine viruses; mortality; lytic infection; lysogeny; protozoan grazing; carbon cycling; HNA; LNA

\section{Introduction}

Marine heterotrophic prokaryotes mediate fundamental processes of biogeochemical cycles and are an integral component of planktonic food webs. Studying the factors driving their spatiotemporal variation is essential for a better understanding of the functioning of marine ecosystems. Flow cytometric analysis of prokaryotes routinely reveals two distinct clusters of prokaryotic cells [1,2], referred to as high nucleic acid fluorescent (HNA) and low nucleic acid fluorescent (LNA) prokaryote populations [3]. While these subpopulations appear to be ubiquitous in aquatic systems [4,5], their relative distributions can vary widely across environmental conditions and geographic regions $[4,6-8]$. To date, studies have largely focused on the role that disparity in the metabolic potential of LNA and HNA cells plays in driving spatiotemporal variations in the relative proportion of these prokaryote subpopulations and 
their activity within and among aquatic systems [1,9-13]. Microbial abundance and activity, however, are a consequence of the net balance between growth and mortality.

Mortality processes regulate biomass, community composition and size structure, and elemental cycling of microbial communities [14-17]. Grazing by phagotrophic protozoans (particularly bacterivorous nanoflagellates) and viral infection are the primary top-down processes regulating heterotrophic prokaryote populations in aquatic environments $[15,18]$. These mortality agents have distinct influences on food web dynamics and ecosystem processes, as they affect the flow of carbon and energy in substantially different ways. Bacterivory is an integral pathway by which dissolved organic carbon (DOC) is reincorporated into the food web via bacterial biomass. The lysis of microbes by viral activity, on the other hand, redirects energy and matter towards microbial reprocessing, enhancing bacterial respiration and the regeneration of nutrients, which are in turn utilized by the primary producers [19-21]. Grazers and viruses also affect the structure of heterotrophic prokaryote communities in very different ways. Grazing modifies prokaryote biomass and size-structure through prey size preference $[15,22,23]$, although some protozoans, particularly flagellates, exhibit partialities for particular prey species or morphotypes $[23,24]$. Viruses, on the other hand, are host-specific and consequently are powerful drivers of biodiversity $[16,25,26]$.

Several studies have explored the potential for mortality processes to regulate the share of prokaryotic subpopulations in natural systems. The proportion of HNA cells has been shown to increase in response to reductions in bacterivores, consistent with size- and activity-selective behavior of flagellates [9,27,28], however, preferential grazing on LNA cells has also been reported [13]. Similarly, viral abundance and the fraction of HNA cells correlated significantly across different aquatic systems [29]. The same study also found a significantly higher abundance of intracellular virus particles in HNA sorted cells within each system. More recently, the abundance and lytic production of two different virus subpopulations were correlated with the cellular production and abundance of HNA and LNA subpopulations in the North Atlantic [30]. Until now, however, the scarcity of concurrent measurements of protozoan grazing and viral mortality within prokaryotic communities have limited our ability directly compare the magnitude by which these mortality sources affect and regulate prokaryotic subpopulations.

Here we assess the prokaryotic abundance and production, relative proportion of LNA and HNA cells in the prokaryote community, viral reproductive strategy (lytic vs. lysogenic), and viral induced mortality relative to grazing of the prokaryotes over a latitudinal gradient across the North Atlantic Ocean during summer stratification. We employ multivariate analysis to identify key factors driving the geographical variation in abundance, growth, and mortality of subprokaryotic populations. Specifically, we assess the following hypotheses: (H1) the heterotrophic prokaryote community production and relative abundance of LNA and HNA cells will vary according to the concentration of phytoplankton carbon in the water column, which is strongly influenced by water column stratification [31]. Due to their reliance on their host to provide the energy and metabolic machinery required for replication (H2) viral abundance, viral replication mode (i.e., lytic and lysogenic) and the production of viruses through lytic infection will vary with heterotrophic prokaryote community production and relative abundance of LNA and HNA cells. Wherein viral abundance and lytic production is positively associated with heterotrophic prokaryote community production and active members of the community. Bacterivorous protozoans, on the other hand, may be directly affected by stratification through alterations in temperature and turbulence [32-36], and consequently be governed by distinct physicochemical forcing. Therefore, we hypothesize that (H3) the abundance and grazing activity of bacterivorous protozoans will be strongly tied to temperature and turbulence in the water column rather than characteristics of their prey community. 


\section{Materials and Methods}

\subsection{Sampling and Physicochemical Parameters}

Thirty-two stations were sampled along a latitudinal gradient in the Northeast Atlantic Ocean during the shipboard expedition of STRATIPHYT which took place onboard of the R/V Pelagia in July-August of 2009 (Figure 1). The water column along the transect was stratified with relatively consistent and shallow mixed layer depths (MLD) ranging from 18-46 $\mathrm{m}$ [37]. Water samples were collected at each station prior to dawn using 24 plastic samplers (General Oceanics type Go-Flow, $10 \mathrm{~L}$ ) mounted on an ultra-clean (trace-metal free) system consisting of a fully titanium sampler frame equipped with CTD (Seabird 9+; standard conductivity, temperature and pressure sensors) and auxiliary sensors for chlorophyll autofluorescence (Chelsea Aquatracka Mk III). Water samples were collected inside a $6 \mathrm{~m}$ clean container. Data from the chlorophyll autofluorescence sensor were calibrated against HPLC data according to van de Poll et al. (2013) [38]. Phytoplankton carbon (PhytoC) was estimated from phytoplankton cell counts obtained using flow cytometry [31].

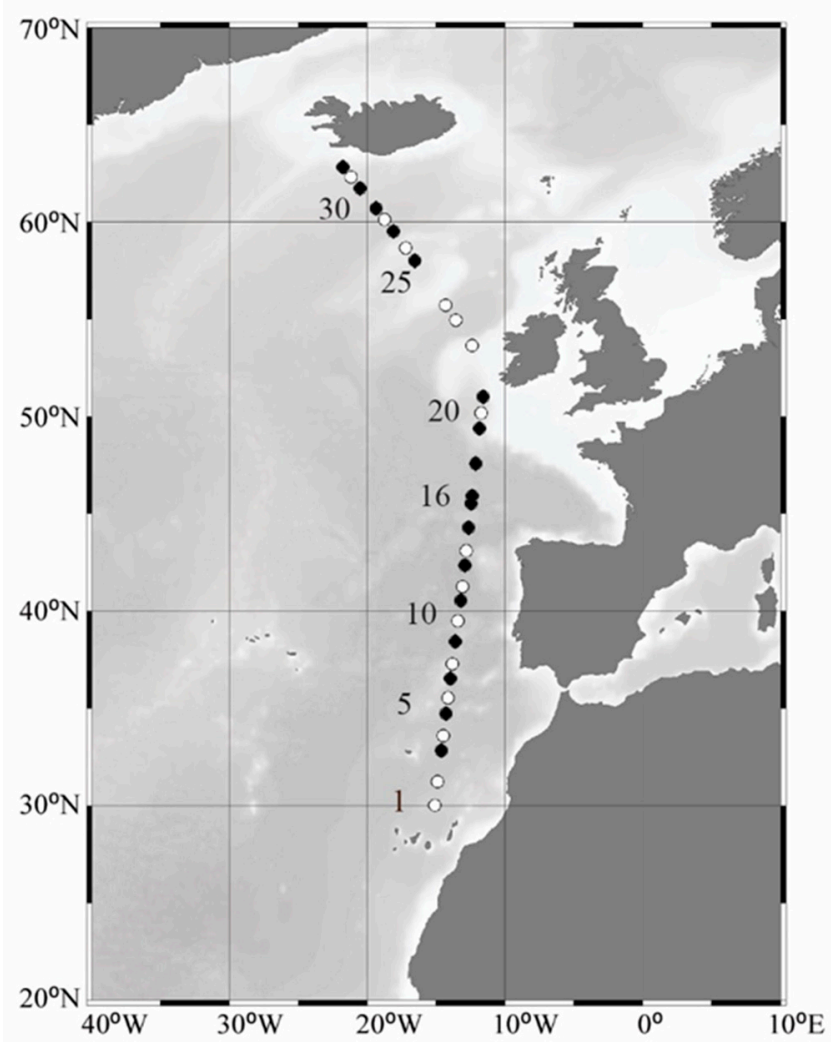

Figure 1. North-south gradient across the Northeast Atlantic Ocean. Bathymetric map depicting stations sampled during the summer STRATIPHYT. Mortality assays to determine viral lysis and microzooplankton grazing rates were performed at stations indicated by black symbols. Figure was prepared using Ocean Data View version 5.2.

Methods and data for temperature eddy diffusivity $\left(\mathrm{K}_{\mathrm{T}}\right)$ and dissolved inorganic nutrients have been discussed previously [31,37]. In short, $\mathrm{K}_{\mathrm{T}}$ (referred to here as vertical mixing) was derived from temperature and conductivity microstructure profiles measured using a SCAMP (self-contained autonomous microprofiler), deployed at 14 stations and down to $100 \mathrm{~m}$ depth. For the additional stations and depths, data were interpolated using the spatial kriging function ' $k$ rig' executed in $\mathrm{R}$ using the 'fields' package. Brunt-Väisälä frequency $\left(\mathrm{N}^{2}\right)$, was used to quantify the strength of stratification and was determined from CTD data processed with SBE Seabird software according to the Fofonoff adiabatic leveling method. 
Samples for dissolved inorganic phosphate $\left(\mathrm{PO}_{4}\right)$, ammonium $\left(\mathrm{NH}_{4}\right)$, nitrate $\left(\mathrm{NO}_{3}\right)$, and nitrite $\left(\mathrm{NO}_{2}\right)$ were gently filtered through $0.2 \mu \mathrm{M}$ pore size polysulfone Acrodisk filters ( $32 \mathrm{~mm}$, Pall Corp., Port Washington, USA) and stored at $-20{ }^{\circ} \mathrm{C}$ until analysis. Dissolved inorganic nutrients were analyzed onboard using a Bran + Luebbe Quaatro AutoAnalyzer for dissolved orthophosphate $\left(\mathrm{PO}_{4}\right)$, inorganic nitrogen (nitrate + nitrite: $\mathrm{NO}_{\mathrm{x}}$ ) and ammonium $\left(\mathrm{NH}_{4}\right)$. Detection limits were $0.10 \mu \mathrm{M}$ for $\mathrm{NO}_{x}, 0.028 \mu \mathrm{M}$ for $\mathrm{PO}_{4}$ and $0.09 \mu \mathrm{M}$ for $\mathrm{NH}_{4}$.

At each station, water samples were obtained from 3-10 depths for the enumeration of heterotrophic prokaryotes (HPA), heterotrophic nanoflagellates (HNF), and viruses (VA) and from three separate depths for heterotrophic prokaryote production (HPP), virus production (VP) and heterotrophic protozoan grazing measurements. Sampling depths for rate-based measurements were classified as: mixed layer (ML; $15 \mathrm{~m}$ ), MID (25-85 m), which contained the deep-chlorophyll maximum (DCM) when present, and DEEP $(100-225 \mathrm{~m})$. The DCM $(47-85 \mathrm{~m})$ was defined by the presence of a subsurface peak in the vertical profile of $\mathrm{Chl} a$ autofluorescence. In addition, at four stations the ML was sampled for a second time prior to dusk (i.e., $7-2,11-2,17-2$ and 30-2).

\subsection{Microbial Abundances}

Heterotrophic prokaryotes (bacteria and archaea) and viruses were enumerated using a Becton-Dickinson FACSCalibur flow cytometer equipped with an air-cooled Argon laser with an excitation wavelength of $488 \mathrm{~nm}(15 \mathrm{~mW})$ according to Marie et al. [39], with modifications according to Mojica et al. [40]. Briefly, samples were fixed with $25 \%$ glutaraldehyde (EM-grade, Sigma-Aldrich, Zwijndrecht, the Netherlands) at a final concentration of $0.5 \%$ for $15-30 \mathrm{~min}$ at $4{ }^{\circ} \mathrm{C}$, flash frozen and stored at $-80{ }^{\circ} \mathrm{C}$ until analysis. Thawed samples were diluted using TE buffer, $\mathrm{pH} 8.2(10 \mathrm{mM}$ Tris-HCL, 1 mM EDTA; Roche, Mannheim, Germany). Prokaryote samples were stained in the dark at room temperature for $15 \mathrm{~min}$ using SYBR Green I at a final concentration of $1 \times 10^{-4}$ of the commercial stock. Virus samples were stained by heating in the dark at $80^{\circ} \mathrm{C}$ for $10 \mathrm{~min}$ in the presence of the nucleic acid-specific green fluorescence dye SYBR Green I at a final concentration of $0.5 \times 10^{-4}$ of the commercial stock concentration (Life Technologies, Bleiswijk, the Netherlands). Trigger for analysis was set on green fluorescence and the obtained list-mode files were analyzed using the freeware, CYTOWIN [41]. Two distinct clusters of prokaryotic cells were distinguished based on their nucleic acid-specific green fluorescence, i.e., a high nucleic acid (HNA) and a low nucleic acid (LNA) fluorescent prokaryote population [1,2]. The contribution of Prochlorococcus to the flow cytometric signal of the HNA subpopulation was assessed using bivariate scatter plots of green versus red chlorophyll autofluorescence. Prochlorococcus was detected in the ML and DCM of the oligotrophic southern stations $\left(<45.5^{\circ} \mathrm{N}\right)$ comprising $11.8 \%$ and $4.7 \%$ of the total prokaryote abundance, respectively. For the enumeration of viruses, only the V1-V3 virus populations [42] were considered in this study.

Heterotrophic nanoflagellates (HNF) were enumerated by epifluorescence microscopy. Briefly, $20 \mathrm{~mL}$ of seawater was fixed using $25 \%$ glutaraldehyde to a final concentration of $1 \%$ ( $10 \%$ working stock, Sigma Aldrich) and stained for $30 \mathrm{~min}$ using 4'6-diamidino-2-phenylindole dihydrochloride (DAPI) (1 mg mL ${ }^{-1}$, Sigma-Aldrich, Zwijndrecht, the Netherlands) at a final concentration of $2 \mu \mathrm{g} \mathrm{mL}{ }^{-1}$. Samples were filtered onto $0.2 \mu \mathrm{M}$ black polycarbonate filter ( $25 \mathrm{~mm}$, Whatman, Maidstone, UK) and stored at $-20^{\circ} \mathrm{C}$. A minimum of 75 fields and $100 \mathrm{HNF}$ in were counted using a Zeiss Axiophot epifluorescence microscope equipped with BP 365, FT395 and LP397 excitation filters. HNF were distinguished by their size, presences of a flagella, and absence of a chloroplast.

\subsection{Heterotrophic Prokaryotic Production}

Heterotrophic prokaryotic production (HPP) was determined from leucine incorporation rates according to Simon and Azam [43]. Ten-milliliter seawater samples were taken in triplicate. One sample was used as a control to which $0.5 \mathrm{~mL}$ formaldehyde (37\%; Sigma-Aldrich, Zwijndrecht, The Netherlands) was added in order to kill the prokaryotes. Thirty $\mu \mathrm{L}[3 \mathrm{H}]$ leucine (specific activity, $139 \mathrm{Ci} \mathrm{mmol}^{-1}$; Amersham, Little Chalfont, UK) was added to each sample, equivalent to $50 \mu \mathrm{Curie}$ 
per vial, and incubated in the dark at in situ temperature for $2 \mathrm{~h}$. Samples were then fixed with $0.5 \mathrm{~mL}$ formaldehyde (37\%; Sigma-Aldrich, Zwijndrecht, the Netherlands) and filtered onto $0.2 \mu \mathrm{M}$ polycarbonate filters ( $25 \mathrm{~mm}$, Whatman, Maidstone, UK). Filters were washed twice by addition of $5 \%$ chilled trichloroacetic acid (TCA) for $5 \mathrm{~min}$ and then transferred to scintillation vials and stored at $-80{ }^{\circ} \mathrm{C}$ until analysis. Prior to analysis, $8 \mathrm{~mL}$ of scintillation cocktail (Filter-Count LCS cocktail; PerkinElmer, Waltham, MS, USA) was added and left for $6 \mathrm{~h}$. Samples were analyzed using a LKB WALLAC 1211 Rackbeta liquid scintillation counter. Heterotrophic prokaryote production, expressed as organic carbon produced, was calculated assuming a carbon to protein ratio of 0.86 and an isotope dilution factor of 2 [43]. Heterotrophic prokaryote production was converted to specific growth rate $\left(\mu ; \mathrm{d}^{-1}\right)$ by dividing by heterotrophic biomass calculated assuming a carbon conversion factor of $12.4 \mathrm{fg} \mathrm{C}$ cell $^{-1}[44]$.

\subsection{Viral Mediated Mortality}

Viral production was determined according to Winget et al. [45]. The aim of this method is to reduce the viral abundance in a sample to a level, which permits the accurate detection and enumeration of newly produced viruses while keeping the bacterial abundance at near ambient concentrations. At in situ temperature and under low light conditions, a $600 \mathrm{~mL}$ whole seawater sample was reduced to approximately $100 \mathrm{~mL}$ by recirculation over a $0.22 \mu \mathrm{M}$-pore-size polyether sulfone membrane (PES) tangential flow filter (Vivaflow 50; Sartorius stedim biotech, Göttingen, Germany) at a filtrate

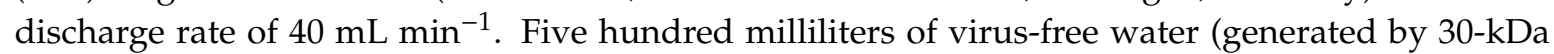
ultrafiltration Vivaflow 200, PES membrane; Sartorius stedim biotech, Göttingen, Germany) was then added. This reduction and resuspension procedure was repeated an additional two times. On the final iteration, the volume was reduced to approximately $50 \mathrm{~mL}$ and the filter was slowly back-flushed to obtain the remaining $50 \mathrm{~mL}$ volume in the system. The sample was then topped up with virus-free water $(500 \mathrm{~mL})$ and aliquoted into six $50 \mathrm{~mL}$ polycarbonate Greiner tubes. Triplicate samples were used to determine viral production due lytic infection, and Mytomycin C (Sigma-Aldrich; $1 \mu \mathrm{g} \mathrm{mL} \mathrm{m}^{-1}$ final concentration) was added the final three samples to determine the lysogenic induction rate from temperate phages. Fifty milliliter triplicate samples of untreated whole seawater and seawater filtered through $0.2 \mu \mathrm{M}$ pore-sizes were also taken to provide estimates of net prokaryotic production and viral loss rates, respectively. One-milliliter subsamples for viral and prokaryotic abundance were taken at the start of the incubation $\left(\mathrm{T}_{0}\right)$, after which the samples were incubated in darkness at in situ temperature and sub-sampled every $3 \mathrm{~h}$ for a total of 12-24 h. Samples were fixed, stored and enumerated as described previously.

Production rate of new viruses was determined from each replicate from the slope of a first-order regression of viral concentration over time. Prophage induction (VPC) was calculated as the difference between virus counts in unamended samples (lytic infection, VP) and those to which Mitomycin C was added. The in situ VP rate was corrected for potential prokaryote and virus loss due to sample processing and adsorption to sample tubes, respectively [45]. Samples showed no significant selective reduction of HNA and LNA cells after sample processing (i.e., two-way ANOVA: interaction between treatment and population $p=0.218$ ). Estimates for daily virus-mediated mortality (VMM, expressed in cells $\mathrm{L}^{-1} \mathrm{~d}^{-1}$ ) were calculated by dividing lytic VP by a burst size of 20 [46].

\subsection{Protozoan Mediated Mortality}

Community grazing rates of prokaryotes were determined using fluorescently labeled natural bacteria (FLB) according to the procedure described by Sherr \& Sherr [47]. Briefly, FLB (FLB stock contained $5 \times 10^{7} \mathrm{~mL}^{-1}$, stored at $-20{ }^{\circ} \mathrm{C}$ until use) were added to one-liter natural whole water samples (polycarbonate bottles) at approximately $10 \%$ of the natural concentration. Immediately after addition, a $20 \mathrm{~mL}$ subsample $\left(\mathrm{T}_{0}\right)$ was taken and fixed with $10 \%$ glutaraldehyde $(1 \%$ final concentration; EM-grade, Sigma-Aldrich, the Netherlands). The sample was then filtered onto a $0.2 \mu \mathrm{M}$ pore-size black polycarbonate filter ( $25 \mathrm{~mm}$, Whatman) and stored at $-20{ }^{\circ} \mathrm{C}$ until analysis. The incubation 
bottles were closed such that no air was trapped inside, mounted on a slow rotating ( 0.5 rpm) plankton wheel, and incubated under in situ light and temperature. After $24 \mathrm{~h}$ incubation, a $20 \mathrm{~mL}$ subsample was taken and treated as previously described. The estimation of grazing rates $\left(\mathrm{d}^{-1}\right)$ were determined as the natural $\log$ of the abundance of FLB in the T24 sample divided by the abundance of FLB in the $\mathrm{T}_{0}$ sample. Protozoan mediated mortality (PMM; $\mathrm{L}^{-1} \mathrm{~d}^{-1}$ ) was calculated as $\mathrm{PMM}=\mathrm{HPA}_{0}-\mathrm{HPA}_{0}{ }^{*} \mathrm{e}^{\mathrm{rt}}$, where $\mathrm{HPA}_{0}$ is the abundance of HPA at the start of the incubation, and $r$ equals the specific grazing rate $\left(\mathrm{d}^{-1}\right)$ obtained from FLB experiments.

\subsection{Statistical Analysis}

Statistical analysis was used to evaluate the potential of the VP method to selectively alter the relative abundance of HNA and LNA cells in the prokaryote community. Specifically, using the R statistical software [48] a two-way ANOVA was applied to all data to test for a significant interaction between treatment (i.e., VP and whole water) and subpopulation (i.e., LNA and HNA). A probability of $\alpha<0.05$ was to determine if the interaction was significant.

To evaluate the hypotheses set forth in the introduction multivariate statistical analysis was applied to the data using the R statistical software supplemented by the vegan package [49]. Data exploration were carried out first according to Zuur et al. [50]. For H1, the response variables were HNA, LNA, the ratio of HNA to LNA cells (HNA:LNA), HPA, HPP and $\mu$. Explanatory variables were latitude, MLD, Chl $a$, temperature, salinity, density, $\mathrm{K}_{\mathrm{T}}, \mathrm{O}_{2}$, PhytoC, $\mathrm{NH}_{4}, \mathrm{PO}_{4}, \mathrm{NO}_{2}$, and $\mathrm{NO}_{3}$. In addition, depth layer was included as factor (i.e., single values per station/sample) to better discriminate how environmental conditions relate to changes in depth. PhytoC was log transformed and $\mathrm{NH}_{4}$ and $\mathrm{NO}_{2} \log (\mathrm{x}+1)$ transformed to improve the homogeneity of variance and reduce the effect of outliers. Next, data were evaluated for collinearity of explanatory variables to obtain the most minimalistic model by calculating variance inflation factors using the $\mathrm{R}$ function corvif [51]. In a step-wise manner, all explanatory variables with variance inflation factors $>10$ were removed from the model. For hypothesis $\mathrm{H1}$, variance inflation factors analysis resulted in the selection of 7 continuous explanatory variables: latitude, $\mathrm{MLD}, \mathrm{K}_{\mathrm{T}}, \mathrm{O}_{2}, \mathrm{NH}_{4}, \mathrm{NO}_{2}$ and PhytoC and depth layer as a factor (levels: ML, MID, and DEEP). Additionally, LNA and HNA were removed as response variables due to their high correlation to HPA abundance (Pearson correlation: $n=32, p$-value $<2.2 \times 10^{-16}, \mathrm{r}=0.98$ and $\mathrm{r}=0.99$, respectively).

For $\mathrm{H} 2$, explanatory variables were temperature, $\mathrm{K}_{\mathrm{T}}, \mathrm{O}_{2}, \mathrm{NH}_{4}, \mathrm{PO}_{4}, \mathrm{NO}_{2}, \mathrm{NO}_{3}, \mathrm{HNA}$ :LNA, HPA, $\mathrm{HPP}, \mu$, ratio of virus to heterotrophic prokaryote (VPR), and depth layer was included as a factor. Total heterotrophic prokaryote abundance, HNA:LNA and VPR were log transformed and $\mathrm{NH}_{4}, \mathrm{NO}_{3}$ and $\mathrm{NO}_{2} \log (\mathrm{x}+1)$ transformed. Exploratory analysis resulted in the selection of 9 continuous explanatory variables for $\mathrm{H} 2$ : temperature, $\mathrm{K}_{\mathrm{T}}, \mathrm{NH}_{4}, \mathrm{NO}_{2}, \mathrm{NO}_{3}, \mathrm{HNA}$ :LNA, HPA, $\mu$, VPR, and, depth layer. The response variables for $\mathrm{H} 2$ were VA, VP and VPC. For comparison, the same set of explanatory variables was used for $\mathrm{H} 3$. For this analysis, data exploration resulted in the selection of temperature, $\mathrm{K}_{\mathrm{T}}, \mathrm{NH}_{4}, \mathrm{NO}_{2}$, HNA:LNA, HPA, HPP, $\mu, \mathrm{VPR}$, and depth layer.

Redundancy analysis (RDA) was applied to test H1-H3 using the three different datasets. RDA is a combination of multiple regression analysis and principal component analysis for multivariate data. Forward selection approach was used to select only explanatory variables that significantly contribute to the RDA model. Significance was assessed by a permutation test, using the multivariate pseudo-F as the test statistic [51]. A total of 9999 permutations were used to estimate $p$-values $(\alpha=0.05)$ associated with the pseudo-F statistic.

\section{Results}

\subsection{Study Site}

Temperature, salinity, and nutrients showed clear depth and latitudinal gradients (Supplement Table S1; [31]). In accordance with strong vertical stratification, the upper water column was 
characterized by low vertical mixing $\left(\mathrm{K}_{\mathrm{T}}\right)$, shallow MLDs (ranging from 19-44 $\mathrm{m}$ ) and relatively high $\mathrm{N}^{2}$ (Table S1; [31]). The southern region $\left(30-45^{\circ} \mathrm{N}\right)$ was classified as oligotrophic based on ML concentrations of $\mathrm{NO}_{3} \leq 0.13 \mu \mathrm{M}$ and $\mathrm{PO}_{4} \leq 0.03 \mu \mathrm{M}$ [38], and Chl $a \leq 0.07 \mu \mathrm{g} \mathrm{L}{ }^{-1}$ [52]. North of this region (i.e., $46-63^{\circ} \mathrm{N}$ ), inorganic nutrient concentrations within the ML increased to average $1.3 \pm 0.7 \mu \mathrm{M} \mathrm{NO}_{3}$ and $0.13 \pm 0.05 \mu \mathrm{M} \mathrm{PO}_{4}$, with highest concentrations north of $58^{\circ} \mathrm{N}$ (stations 25-32) averaging $1.53 \pm 0.43 \mu \mathrm{M}$ and $0.15 \pm 0.03 \mu \mathrm{M}$, respectively. Accordingly, Chl $a$ and PhytoC concentrations in the surface ML increased along the meridional transect with subsurface maxima (i.e., DCM) present in stations of the oligotrophic region (Figure 2a,b). Specifically, average Chl $a$ concentrations in the ML increased from $0.06 \pm 0.02 \mu \mathrm{g} \mathrm{L}-1$ in the oligotrophic region to $1.1 \pm 0.2 \mu \mathrm{g} \mathrm{L}^{-1}$ north of $58^{\circ} \mathrm{N}$ (Figure 2a). Similarly, PhytoC increased from $3.8 \pm 2.4 \mu \mathrm{g} \mathrm{C} \mathrm{L}^{-1}$ to $56.9 \pm 37.5 \mu \mathrm{g} \mathrm{C} \mathrm{L}^{-1}$ (Figure 2b). Inorganic nutrients in the DCM (i.e., MID depth samples) averaged $0.55 \pm 0.72 \mu \mathrm{M} \mathrm{NO}_{3}$ and $0.06 \pm 0.06 \mu \mathrm{M} \mathrm{PO}_{4}$, a marginal increase compared to the ML concentrations. In contrast, average Chl $a$ and PhytoC concentrations in the DCM increased 7.5- and 2.6-fold compared to ML values (i.e., DCM $0.45 \pm 0.25 \mu \mathrm{g} \mathrm{L}{ }^{-1}$ and $10.0 \pm 6.2 \mu \mathrm{g} \mathrm{C} \mathrm{L}{ }^{-1}$, respectively). At stations without a DCM, MID depth nutrient concentrations increased 4.8- and 3.5-fold compared to ML concentrations, averaging $5.47 \pm 3.19 \mu \mathrm{M} \mathrm{NO}_{3}$ and $0.42 \pm 0.19 \mu \mathrm{M} \mathrm{PO}_{4}$ and $\mathrm{Chl} a$ and PhytoC increased to $0.53 \pm 0.28 \mu \mathrm{g} \mathrm{L}^{-1}$ and $35.21 \pm 35.18 \mu \mathrm{g} \mathrm{C} \mathrm{L}^{-1}$, respectively. Below $100 \mathrm{~m}$, inorganic nutrients in the oligotrophic region averaged of $0.4 \pm 0.1 \mu \mathrm{M}$ and $7.2 \pm 1.6 \mu \mathrm{M}$ for $\mathrm{PO}_{4}$ and $\mathrm{NO}_{3}$, respectively. The northern region had similar nutrient concentrations in DEEP samples averaging $0.7 \pm 0.1 \mu \mathrm{M}$ and $11.1 \pm 1.5 \mu \mathrm{M}$ for $\mathrm{PO}_{4}$ and $\mathrm{NO}_{3}$. PhytoC and $\mathrm{Chl} a$ concentrations were low in DEEP samples and varied little over the latitudinal transect. Accordingly, PhytoC and Chl $a$ in DEEP samples averaged $0.01 \pm 0.01 \mu \mathrm{g} \mathrm{L}^{-1}$ and $0.02 \pm 0.01 \mu \mathrm{g} \mathrm{C} \mathrm{L}{ }^{-1}$ in the southern oligotrophic region, and $0.02 \pm 0.01 \mu \mathrm{g} \mathrm{L}^{-1} 0.21 \pm 0.23 \mu \mathrm{g} \mathrm{C} \mathrm{L}^{-1}$ in the north, respectively.
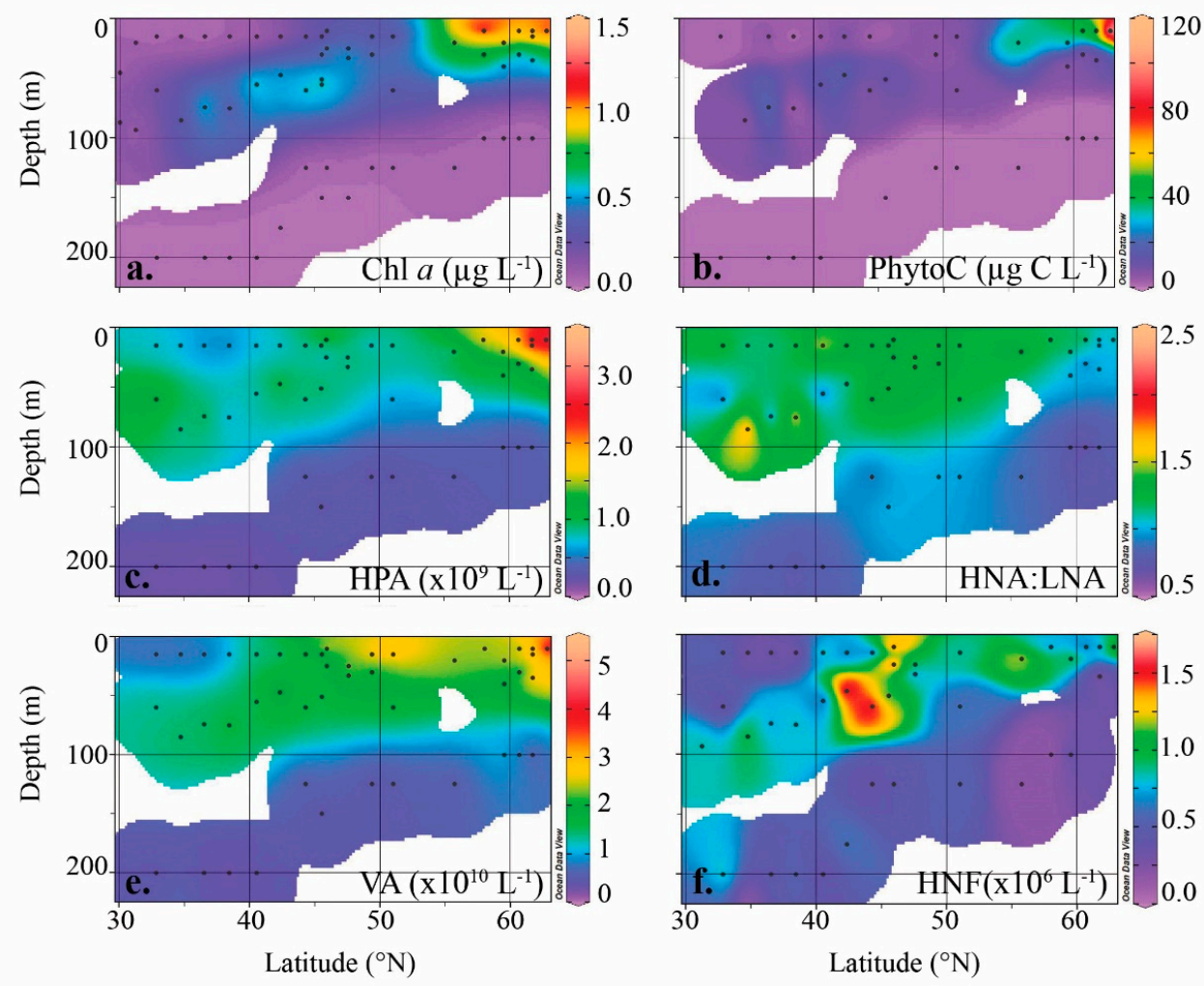

Figure 2. Biogeographical distributions of (a) Chl $a$, (b) phytoplankton carbon (PhytoC), (c) heterotrophic prokaryote abundance (HPA), (d) high nucleic acid fluorescent (HNA):low nucleic acid fluorescent (LNA), (e) virus abundance (VA), and (f) heterotrophic nanoflagellate abundance (HNF) across the Northeast Atlantic Ocean obtained during the STRATIPHYT cruise. Black dots indicate sampling points. Graphs were prepared with Ocean Data View version 5.2. 


\subsection{Heterotrophic Prokaryotes}

The abundance of the heterotrophic prokaryotes was consistently low in the surface mixed layer (ML) until $58^{\circ} \mathrm{N}$, with an average $6.9 \pm 1.1 \times 10^{8}$ prokaryotes $\mathrm{L}^{-1}$ in the oligotrophic region and increasing to an average of $17.6 \pm 9.8 \times 10^{8} \mathrm{~L}^{-1}$ in the north (Figure 2c). At MID depths, in the southern regions with a DCM, abundances were slightly higher compared to the ML averaging $9.6 \pm 2.3 \times 10^{8}$ prokaryotes $\mathrm{L}^{-1}$. Conversely, in the north, abundances were lower than ML values averaging $8.0 \pm 2.8 \times 10^{8}$ prokaryotes $\mathrm{L}^{-1}$. The HNA prokaryote population tended to numerically dominate at both the ML and MID depths (Figure 2d), comprising on average $55.5 \pm 4.4$ and $52.5 \pm 9.4 \%$ of the total counts, respectively. The fraction of HNA varied little with latitude, with only a slight (i.e., $~ 2 \%$ ) decrease between the southern and northern regions of the transect. Lowest heterotrophic prokaryote abundances were measured in DEEP samples with average concentrations ranging from $2.2 \pm 0.3 \times 10^{8} \mathrm{~L}^{-1}$ in the south to $2.9 \pm 0.5 \times 10^{8} \mathrm{~L}^{-1}$ in the north. The LNA population also had its greatest contribution to total prokaryotic abundance at this depth, comprising on average $54.0 \pm 4.3 \%$ of the total counts (Figure 2d).

The heterotrophic prokaryote production in the ML increased steadily with latitude from 0.83 to $5.3 \mu \mathrm{g} \mathrm{C} \mathrm{L}^{-1} \mathrm{~d}^{-1}$ (Figure 3). Similar to abundance, highest production rates were measured in the northern most stations $\left(>58^{\circ} \mathrm{N}\right)$ with an average production of $4.5 \pm 0.8 \mu \mathrm{g} \mathrm{C} \mathrm{L}^{-1} \mathrm{~d}^{-1}$. There was very little variation in production in ML and MID depth samples of the southern oligotrophic region (on average $1.4 \pm 0.7$ and $1.5 \pm 0.6 \mu \mathrm{g} \mathrm{C} \mathrm{L}^{-1} \mathrm{~d}^{-1}$, respectively). In the northern region, however, heterotrophic prokaryote production was on average slightly lower at MID depths (i.e., $2.0 \pm 1.0 \mu \mathrm{g} \mathrm{C}$ $\mathrm{L}^{-1} \mathrm{~d}^{-1}$ ) compared to ML values (i.e., $2.8 \pm 1.6 \mu \mathrm{g} \mathrm{C} \mathrm{L}^{-1} \mathrm{~d}^{-1}$ ). Heterotrophic production was reduced in

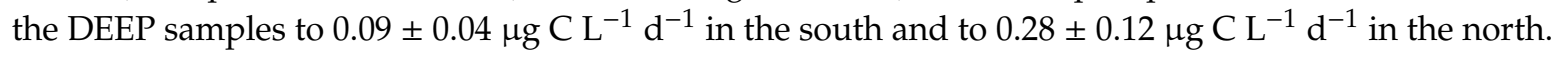

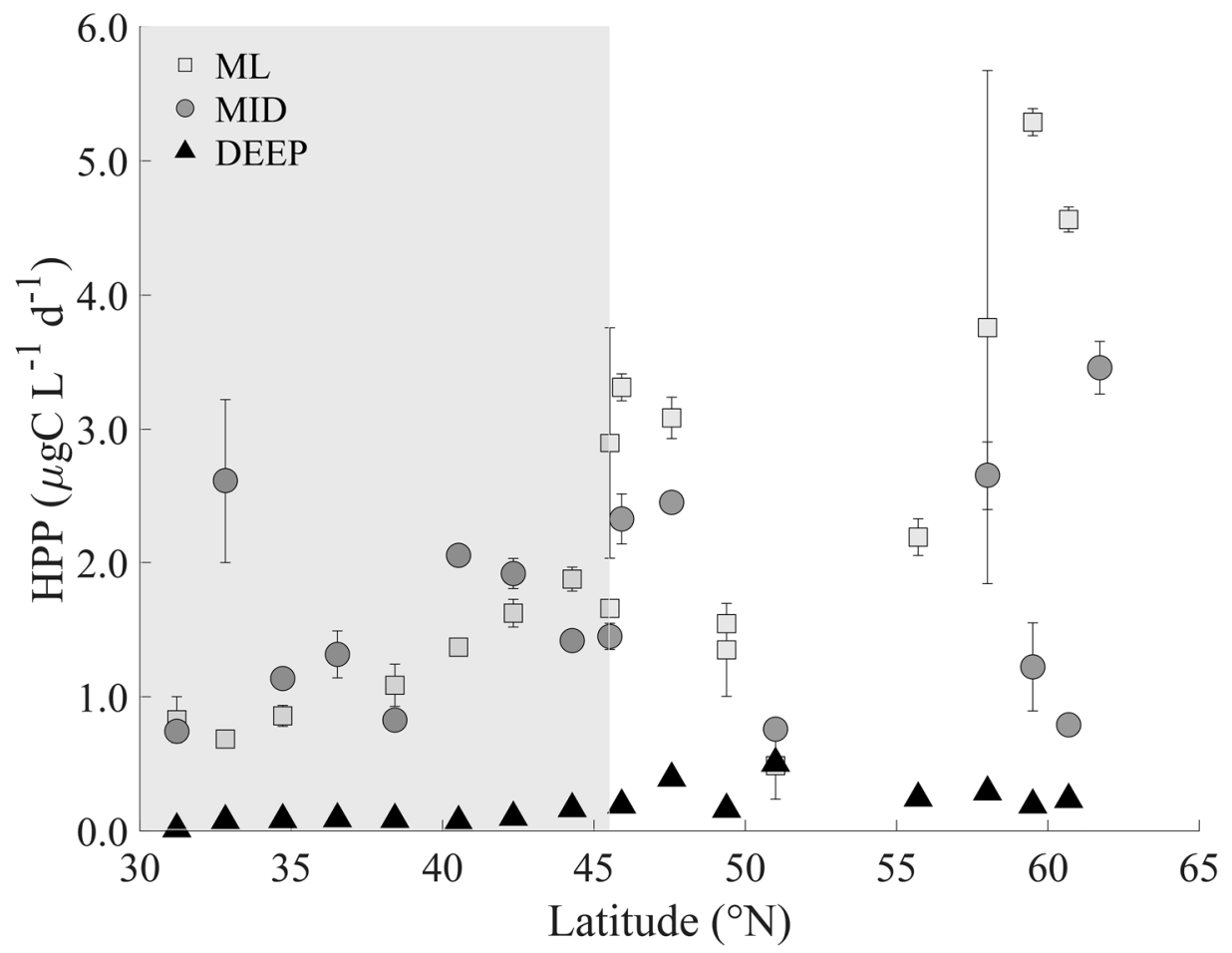

Figure 3. Heterotrophic prokaryote production (HPP) measured in the Northeast Atlantic during the summer STRATIPHYT cruise. Rates were obtained from 3 separate depths: the mixed layer (ML; $15 \mathrm{~m}$ ), below the mixed layer (MID; 25-85 m), which included the deep-chlorophyll maximum where present (DCM; 47-85 m; defined by the presence of a subsurface peak in the vertical profile of Chl $a$ autofluorescence), and deep (DEEP; $100-225 \mathrm{~m})$. Error bars represent standard error $(n=3)$. The gray shaded area represented the latitudinal range of stations with a DCM present. 
In order to ascertain key physicochemical parameters for the abundance and production of heterotrophic prokaryotes within our study, we applied a redundancy analysis (RDA) to our data. Forward selection revealed that only PhytoC and nitrate significantly contributed to the RDA model for H1 (Akaike Information Criterion (AIC): 21.74 and 18.82, F-statistic: 36.77 and 4.74, p-value: 0.005 and 0.010 , respectively), explaining $56.9 \%$ and $4.5 \%$ of the variation in the data, respectively. Heterotrophic prokaryote abundance and activity at ML and MID depths was positively associated with PhytoC concentrations. Conversely, DEEP samples were characterized by low PhytoC and high nutrient concentrations and were associated with low prokaryote abundance, production, and cell specific growth rates, and a higher proportion of LNA cells. Oligotrophic stations (as indicated by the presence of a DCM) were characterized by lower nutrient and PhytoC concentrations, and were associated with higher HNA:LNA and lower prokaryote production and cell specific growth rates.

\subsection{Viruses}

Similar to heterotrophic prokaryote abundances, viral abundances were lowest in the ML of oligotrophic stations (average $11.0 \pm 3.6 \times 10^{9} \mathrm{~L}^{-1}$; Figure $2 \mathrm{e}$ ) and increased at the oligotrophic boundary $\left(\sim 45^{\circ} \mathrm{N}\right)$ to average $29.0 \pm 9.5 \times 10^{9}$ viruses $\mathrm{L}^{-1}$. The highest viral abundance of $52.6 \times 10^{9} \mathrm{~L}^{-1}$ were measured in the ML at station 32. Viral abundances were slightly higher at MID depths compared to overlying ML at oligotrophic stations, i.e., $16.2 \pm 4.2 \times 10^{9} \mathrm{~L}^{-1}$ and increased only slightly in the northern region $\left(18.3 \pm 10.9 \times 10^{9} \mathrm{~L}^{-1}\right)$. Lowest abundances were measured in DEEP samples and varied little with latitude (increasing from $4.1 \pm 1.2$ in the south to $5.9 \pm 3.1 \times 10^{9} \mathrm{~L}^{-1}$ in the northern region). Average virus-to-prokaryote ratio (VPR) varied little between ML and MID depths but both showed an increase between the southern region (16.2 \pm 4.8 and $17.5 \pm 5.1)$ and northern region of the transect (22.0 \pm 14.2 and $21.7 \pm 6.8$, respectively). Conversely, DEEP samples showed little variation in VPR between the two regions, i.e., $19.1 \pm 6.4$ and $20.3 \pm 9.5$, respectively. The V1 virus group dominated the viral community, comprising on average $68.7 \pm 8.0 \%$ of the total counts. The contribution V1 to total virus abundance increased between the south and northern regions, with greatest differences measured in the ML and MID depths (ML: $62 \pm 5$ to $75 \pm 4 \%$, MID: $65 \pm 7$ to $71 \pm 11 \%$ and DEEP: $69 \pm 7$ to $71 \pm 10 \%$ ).

Rates of total lytic virus production at ML and MID depths were largely a reflection of the production of viruses of the V1 group (i.e., $94.3 \pm 19.4 \%$ ). In the ML, lytic virus production increased from $0.6 \pm 0.4 \times 10^{10}$ viruses $\mathrm{L}^{-1} \mathrm{~d}^{-1}$ in the oligotrophic south to $1.5 \pm 1.7 \times 10^{10}$ viruses $\mathrm{L}^{-1} \mathrm{~d}^{-1}$ in the north (Figure 4a), resulting in a greater than 2-fold increase in virus-mediated mortality from $3.0 \pm 1.7$ to $7.5 \pm 8.3 \times 10^{8}$ cell lysed $\mathrm{L}^{-1} \mathrm{~d}^{-1}$. The prophage induction rates in ML samples of the south were about a third of the lytic production rates, averaging $0.2 \pm 0.3 \times 10^{10} \mathrm{~L}^{-1} \mathrm{~d}^{-1}$ (Figure $4 \mathrm{~b}$ ). Measurable rates of prophage induction in the north were relatively low (compared to lytic production) and detected at only 4 stations (i.e., 16, 19, 25 and 30-2), averaging $0.1 \pm 0.2 \times 10^{10}$ viruses $\mathrm{L}^{-1} \mathrm{~d}^{-1}$. In the MID depth samples of the south, lytic virus production rates were comparable to ML values, i.e., $0.8 \pm 0.6 \times 10^{10}$ viruses $\mathrm{L}^{-1} \mathrm{~d}^{-1}$ or $3.0 \times 10^{8}$ cell lysed $\mathrm{L}^{-1} \mathrm{~d}^{-1}$. Although viral production was only determined at MID depths at 3 stations in the north $(16,18,21)$, rates increased from $0.5 \times 10^{10}$ to $1.8 \times 10^{10} \mathrm{~L}^{-1} \mathrm{~d}^{-1}$ corresponding to a viral mediated morality ranging from 2.7 to $8.8 \times 10^{8}$ cell lysed $\mathrm{L}^{-1} \mathrm{~d}^{-1}$. The highest rates of prophage induction were recorded in the MID depth samples from the DCM of the oligotrophic region which averaged $0.5 \pm 0.7 \times 10^{10}$ viruses produced $\mathrm{L}^{-1} \mathrm{~d}^{-1}$. Moreover, the prophage induction rates within these samples declined hyperbolically with latitude (Figure $4 \mathrm{~b}$ ).

Figure 5a illustrates the most parsimonious RDA model for hypothesis $\mathrm{H} 2$. Forward selection revealed that VPR, HPA, HNA:LNA and $\mathrm{K}_{\mathrm{T}}$ all significantly contributed to the RDA model at an $\alpha$ of 0.05 . The first two axes of the RDA triplot (Figure 5a) were driven by VPR and HNA:LNA and explained $43.7 \%$ and $11.3 \%$ of the variation in the data, respectively. Lytic virus production was inversely associated to HNA:LNA and $\mathrm{K}_{\mathrm{T}}$ and positively to heterotrophic prokaryote abundance (HPA). Conversely, stations with low VPR, viral abundance, and $\mathrm{K}_{\mathrm{T}}$ were associated with higher prophage induction rates. Moreover, viral abundance and lytic production were not strongly coupled. 
Stations outside the oligotrophic region (i.e., no DCM; right quadrants) were characterized by higher abundances of heterotrophic prokaryotes and viruses, and thus were also associated with higher VPR.
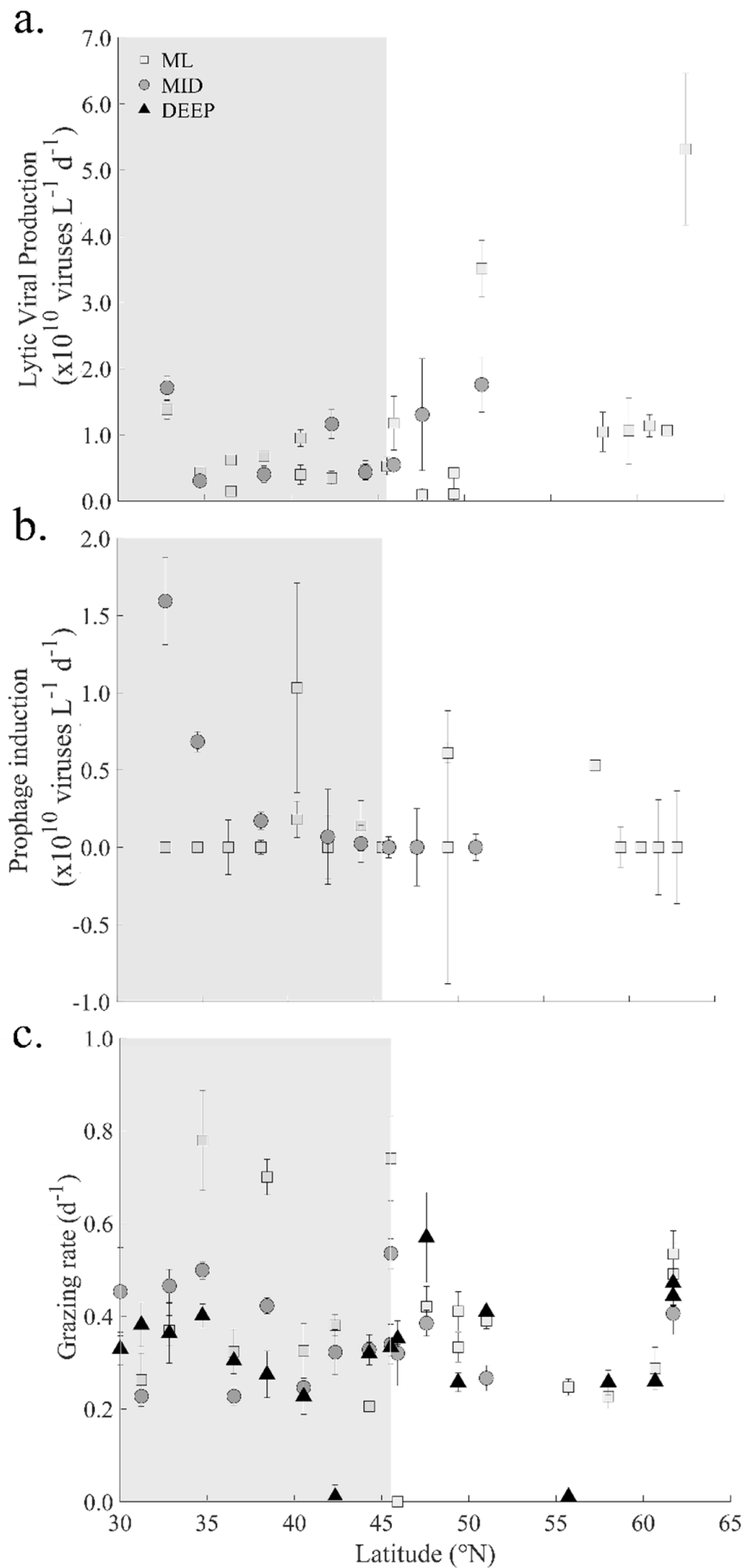

Figure 4. Average rates of viral and grazing activity within prokaryotes communities in the Northeast Atlantic during the summer STRATIPHYT cruise. Daily rates of (a) lytic viral production (VP), (b) Mitomycin C prophage induction (VPC), and (c) microzooplankton grazing. Rates were obtained from three separate depths: the mixed layer (ML; $15 \mathrm{~m}$ ), below the mixed layer (MID; 25-85 m), which included the deep-chlorophyll maximum where present (DCM; 47-85 m; defined by the presence of a subsurface peak in the vertical profile of $\mathrm{Chl} a$ autofluorescence), and deep (DEEP; 100-225 m). Error bars represent standard error $(n=3)$. Gray shaded area represented the latitudinal range of stations with a DCM present. 


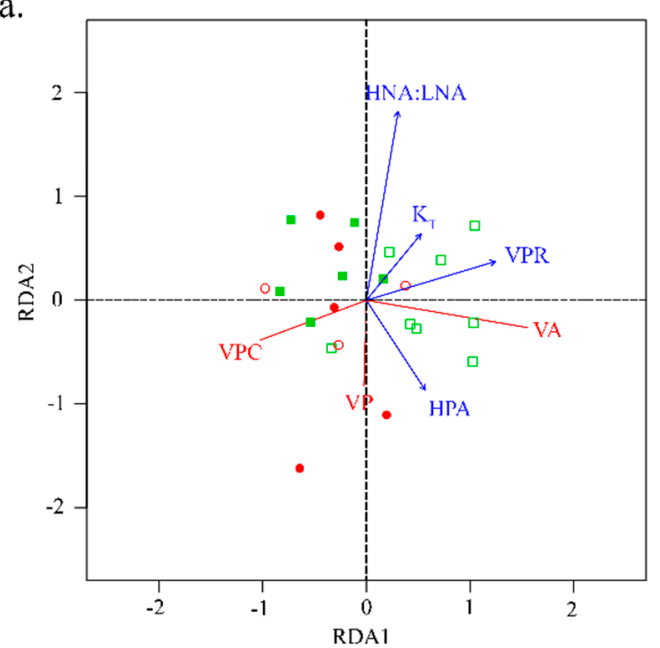

b.

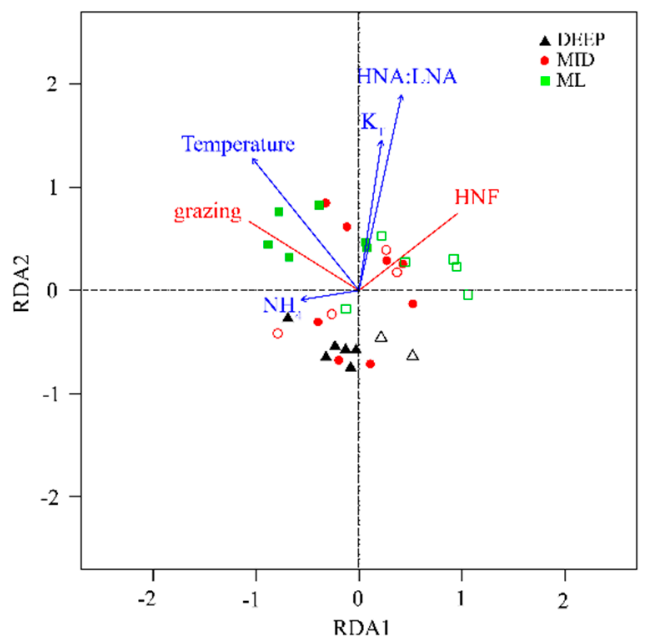

Figure 5. Redundancy analysis (RDA) correlation triplots of factors important in structuring the abundance and activity of mortality agents of (a) viruses and (b) heterotrophic nanoflagellates during STRATIPHYT. Response variables are shown in red and explanatory variables in blue. Symbols represent individual sampling points (a: $n=22$ and $\mathrm{b}: n=32)$ and illustrate from what depth layer samples originated; shape and color coded according to the depth layer and filled according to the presence or absence of a deep-chlorophyll maximum (closed = present and open = absent). The total variance explained by the RDA models in panel $\mathrm{a}$ and $\mathrm{b}$ were $58.8 \%$ and $38.9 \%$, respectively. Abbreviations represent viral abundance (VA), lytic viral production (VP), Mitomycin C prophage induction (VPC), virus-to-prokaryote ratio (VPR), heterotrophic prokaryote abundance (HPA), nitrate $\left(\mathrm{NO}_{3}\right)$, HNA to LNA ratio (HNA:LNA), ammonium $\left(\mathrm{NH}_{4}\right)$, vertical mixing coefficient $\left(\mathrm{K}_{\mathrm{T}}\right)$, and heterotrophic nanoflagellate abundance (HNF).

\subsection{Heterotrophic Protists}

The abundance of HNF in the ML increased nearly 2-fold from south to north, i.e., $5.1 \pm 2.1$ to $9.6 \pm 2.6 \times 10^{5} \mathrm{~L}^{-1}$ (Figure 2f). At oligotrophic sites, HNF abundances at MID depths were on average about 2-fold higher compared to ML values (i.e., $9.6 \pm 4.1 \times 10^{5} \mathrm{HNF} \mathrm{L}^{-1}$ ). In the north, however, the abundances of HNF were reduced at MID depths compared to the ML (i.e., $7.8 \pm 5.2 \times 10^{5} \mathrm{~L}^{-1}$ ). Lowest HNF abundances were measured in DEEP samples, decreasing slightly from $4.9 \pm 1.9 \times 10^{5} \mathrm{~L}^{-1}$ in the south to $3.4 \pm 1.7 \times 10^{5} \mathrm{~L}^{-1}$ at northern stations. Despite lower abundances of HNF, the specific community grazing rates were on average higher at oligotrophic stations compared to those measured at stations in the north (averaging $0.45 \pm 0.22$ and $0.33 \pm 0.15 \mathrm{~d}^{-1}$, respectively). When extrapolated to protist mediated mortality, rates increased from $2.3 \pm 8.6 \times 10^{8}$ in the south to $4.9 \pm 4.2 \times 10^{8}$ cells grazed $\mathrm{L}^{-1} \mathrm{~d}^{-1}$ in the north. Samples from MID depths showed very little variation in measured community grazing rates and protist mediated mortality between the two regions (i.e., $0.37 \pm 0.11$ $\mathrm{d}^{-1}$ compared to $0.34 \pm 0.06 \mathrm{~d}^{-1}$ and $3.0 \pm 1.1 \times 10^{8}$ cells grazed $\mathrm{L}^{-1} \mathrm{~d}^{-1}$ compared to $2.6 \pm 1.3 \times 10^{8}$ cells grazed $\mathrm{L}^{-1} \mathrm{~d}^{-1}$, respectively). Community grazing rates in DEEP samples were still relatively high $\left(0.29 \pm 0.11 \mathrm{~d}^{-1}\right.$ in the south and $0.34 \pm 0.16 \mathrm{~d}^{-1}$ in the north) compared to HNF abundances measured at those depths (Figure 4c). Protist mediated mortality in DEEP samples increased slightly from $0.5 \pm 0.2 \times 10^{8}$ cells grazed $\mathrm{L}^{-1} \mathrm{~d}^{-1}$ within the oligotrophic region to $0.7 \pm 0.5 \times 10^{8}$ cells grazed $\mathrm{L}^{-1} \mathrm{~d}^{-1}$ in the north.

Figure $5 \mathrm{~b}$ illustrates the RDA model for hypothesis H3. Forward selection revealed that temperature, HNA:LNA, and $\mathrm{K}_{\mathrm{T}}$ significantly contributed to the RDA model at an $\alpha$ of 0.05 . Ammonium was slightly below $(p=0.055)$ the set alpha, however, it was retained in the final model as it significantly contributed to the constrained portion of the variance. Nevertheless, a large proportion (53\%) of unconstrained variation remained (i.e., variation in response variables that is non-redundant with the variation in response variables). The first two axes of the RDA triplot explained $26.2 \%$ and $12.8 \%$ 
of the variation in the data, respectively. Temperature (negative direction) was the main variable contributing to the formation of the first axis, while the second axis was driven by HNA:LNA and $\mathrm{K}_{\mathrm{T}}$. Stations characterized by increased $\mathrm{K}_{\mathrm{T}}$, higher HNA:LNA and lower $\mathrm{NH}_{4}$ were associated with higher $\mathrm{HNF}$ abundances. Increased community grazing grates were associated with higher temperature environments. Interestingly, HNF abundance was not correlated to either temperature or community grazing rate (i.e., in a RDA plot correlations are reflected in the angles between lines, wherein a $90^{\circ}$ angle represents no correlation).

\subsection{Heterotrophic Prokaryote Mortality}

Averaged over the ML and MID depths, total mortality increased from $6.4 \pm 2.9$ in the oligotrophic southern region to $9.3 \pm 5.5$ cells $\mathrm{L}^{-1} \mathrm{~d}^{-1}$ in the north. Specifically, total mortality in the ML increased from an average of $5.8 \pm 1.9$ to $9.8 \pm 6.3 \times 10^{8}$ cells $\mathrm{L}^{-1} \mathrm{~d}^{-1}$, and at MID depths increased from $7.3 \pm 4.0 \times 10^{8}$ cells $\mathrm{L}^{-1} \mathrm{~d}^{-1}$ to $8.0 \pm 3.2 \times 10^{8}$ cells $\mathrm{L}^{-1} \mathrm{~d}^{-1}$. In general, prokaryotic losses were dominated by virus mediated mortality (Table 1$)$.

The ratio of total microbial-mediated mortality (TMM; VMM + PMM) to total available prokaryotic carbon (TAC; standing stock biomass + production) in the ML and MID samples showed a gradual decrease in oligotrophic region from around 1.0 to 0.4 (Figure 6). North of $45^{\circ} \mathrm{N}$, the ML increased from around 0.2 to 0.4 before reaching a maximum of 1.9 at $51^{\circ} \mathrm{N}$ that was the closest near-shore station sampled (Station 21$)$. In the northern most region $\left(>58^{\circ} \mathrm{N}\right)$, TMM:TAC averaged 0.5. The MID depth showed a similar trend, increasing north of $45^{\circ} \mathrm{N}$ from 0.5 to 0.8 before reaching also reaching a maximum of 1.5 at station 21 .

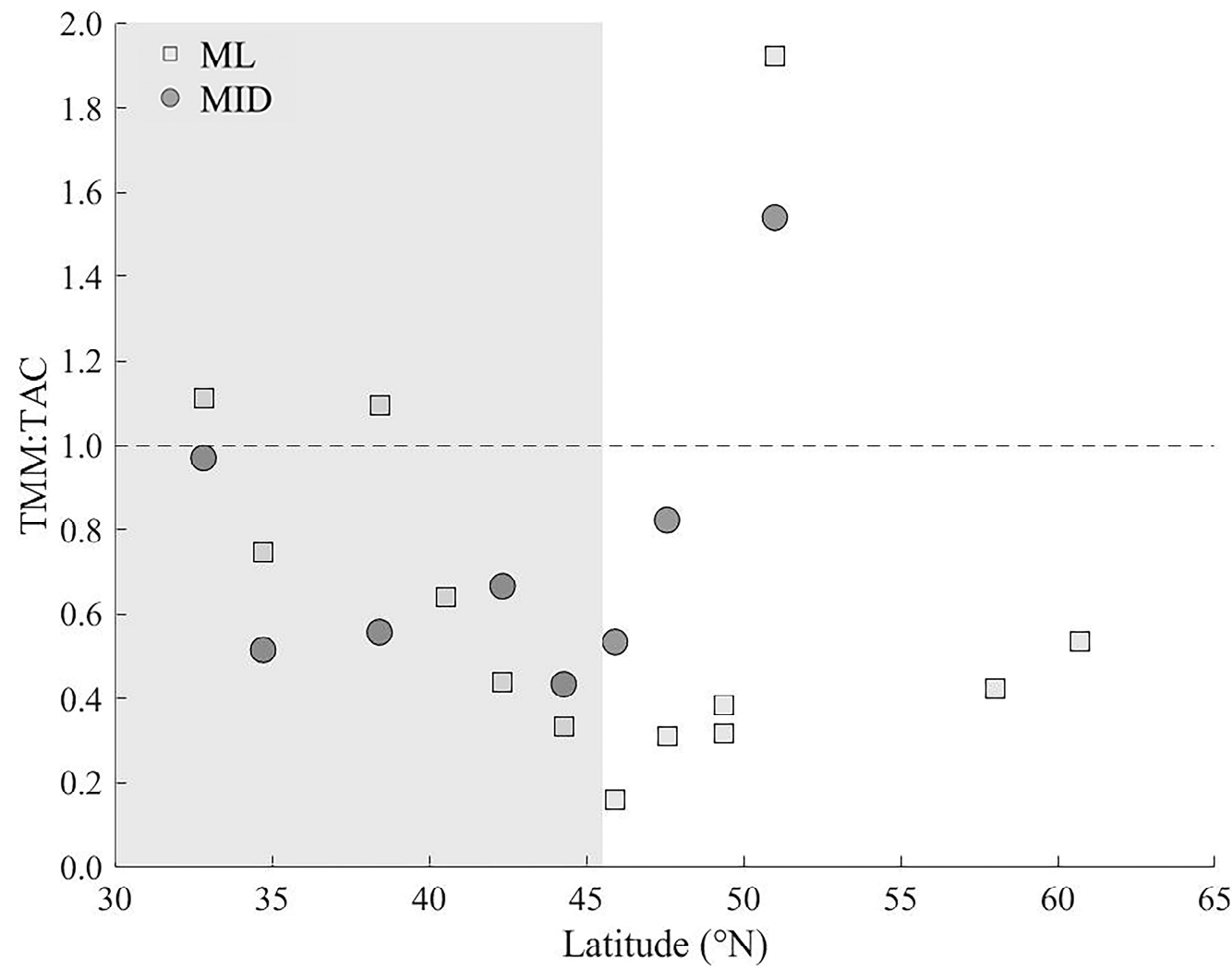

Figure 6. The ratio of total microbial mediated mortality (TMM; VMM + PMM) to total available prokaryotic carbon (TAC; standing stock biomass + production) as a function of latitude for the ML and MID depth samples. The gray shaded area represented the latitudinal range of stations with a DCM present. 
Table 1. Summary of heterotrophic prokaryote mortality rates. Data for total microbial-mediated mortality (TMM), viral-mediated mortality (VMM) and protist-mediated mortality (PMM) are presented as averages $\left(\times 10^{8}\right.$ cells $\left.\mathrm{L}^{-1} \mathrm{~d}^{-1}\right) \pm$ standard deviation for the mixed layer $(\mathrm{ML} ; 15 \mathrm{~m})$ and mid sampling depths (MID; $25-85 \mathrm{~m}$ ) of the southern $\left(\mathrm{S} ; 30-45^{\circ} \mathrm{N}\right)$ and northern $\left(\mathrm{N} ; 46-63^{\circ} \mathrm{N}\right)$ regions of the meridional transect.

\begin{tabular}{ccccc}
\hline & \multicolumn{2}{c}{ ML } & \multicolumn{2}{c}{ MID } \\
\cline { 2 - 5 } & $\mathbf{S}$ & $\mathbf{N}$ & $\mathbf{S}$ & $\mathbf{N}$ \\
\hline VMM & $3.0 \pm 1.8$ & $5.4 \pm 5.1$ & $4.0 \pm 3.1$ & $6.0 \pm 3.1$ \\
PMM & $2.3 \pm 0.9$ & $4.9 \pm 4.2$ & $3.0 \pm 1.1$ & $2.6 \pm 1.3$ \\
TMM & $5.8 \pm 1.9$ & $9.8 \pm 6.3$ & $7.3 \pm 4.0$ & $8.0 \pm 3.2$ \\
\hline
\end{tabular}

\section{Discussion}

\subsection{Heterotrophic Prokaryote Abundance and Activity}

Our study area in the North Atlantic Ocean offered a large-scale gradient from permanently stratified subtropics to the seasonal stratified temperate region [31,53]. Heterotrophic prokaryote abundance, production, and cell specific growth were all tightly coupled to $\mathrm{Chl} a$ and phytoplankton carbon concentrations. Vertical stratification was found to play an important role in regulating the size and composition of phytoplankton communities in this area during the time of our study [31]. The results presented here suggest that these alterations in phytoplankton biomass have direct consequences for heterotrophic prokaryotes. Phytoplankton and heterotrophic prokaryotes are inherently linked by their opposing roles as the primary producers and consumers of dissolved organic matter, respectively, and consequently co-vary across a wide range of aquatic ecosystems [54-56]. A strong correlation between heterotrophic prokaryote production and specific growth rates also indicates that the variability in specific growth rate (i.e., production/biomass) was an important mechanism governing prokaryote production. The availability of dissolved organic carbon is considered as the primary factor regulating heterotrophic prokaryote activity in marine systems [57-59]. For our data, phytoplankton carbon alone explained more than half $(\sim 57 \%)$ of the variability in heterotrophic prokaryotic community dynamics. Accordingly, food web processing (i.e., dissolved organic matter release, sloppy feeding, viral lysis, etc.) likely provided a vital source of available DOC for the heterotrophic prokaryotic community.

The HNA cells are typical (but not always; $[10,13,60]$ ) considered to be the more active subpopulation within a heterotrophic prokaryote community and are often associated with higher cell-specific activity rates compared to LNA cells $[10,61]$. Indeed, our results reveal a positive association of HNA:LNA with prokaryotic production and specific growth rate, suggesting a higher metabolic activity of HNA cells $[1,62,63]$. Accordingly, the proportion of HNA cells in a community is generally expected to be positively associated with ecosystem productivity. However, our results reveal HNA cells as a predominant component of the prokaryote community of the southern oligotrophic subtropical region. Higher percentages of HNA cells have been reported for the DCM, but in general the proportion of LNA cells is typically been found to increase with oligotrophy $[7,8,64]$. Moreover, there was a discernible decrease in HNA:LNA in the surface waters north of $58^{\circ}$ where productivity was maximal. At the time of this study, phytoplankton mortality at low and mid latitudes was dominated by viral mortality, shifting to a grazing dominated system at higher latitudes $\left(>56^{\circ} \mathrm{N}\right)$ [42]. Phytoplankton mortality has substantial effects on the production and composition of DOM, and consequently on the activity and composition of the surrounding heterotrophic prokaryote community [20,21,65-67]. In order to examine the relationship between phytoplankton mortality mode (i.e., virus versus grazing) previously reported [42] and the trends in HNA:LNA of the current study, we combined data for all stations and depths where simultaneous measurements were acquired. For optimal comparison of the data, the ratio of viral lysis to grazing rate of phytoplankton populations were averaged across all groups with maxima capped at 5.5. Indeed, we found a significant positive correlation between phytoplankton mortality mode and HNA:LNA (Pearson $r=0.6, n=14, p$-value $=0.005$ ). Accordingly, 
phytoplankton mortality processes likely played a major role in the distribution of heterotrophic prokaryote subpopulations during our study.

The HNA prokaryotes often have a strong phylogenetic association with copiotrophic members of Bacteroidetes, Gammaproteobacteria, and Aphaproteobacteria [1,68]. A common characteristic of many of these copiotrophic strains is their propensity to respond to and utilize proteins, peptides, and complex polysaccharides, particularly those associated with phytoplankton blooms [69-71]. This may provide them with a selective advantage that enables them to successfully exploit transient nutrient bursts, like those associated with the cell leakage and lysis due to viral infection. Indeed, viral infection and lysis of phytoplankton has been linked to enrichment of HNA cells and associated taxa (i.e., Gammaproteobacteria and Aphaproteobacteria) in marine prokaryotic communities [20,67]. The inverse association between HNA:LNA and nitrate, which has also been reported previously for the Atlantic [8,72], may then be indicative of a reduced reliance of HNA cells on inorganic sources of nitrogen (cellular material released due to lysis is rich in organic phosphorus and nitrogen compounds).

\subsection{Viral Mediated Mortality of Heterotrophic Prokaryotes}

Viral proliferation is dependent upon its hosts, consequently virus abundance often co-varies with their numerically dominate hosts-the heterotrophic prokaryotes [73-75]. Accordingly, viral abundance and the fraction of V1 viruses in our community were strongly associated with ecosystem productivity. In addition to host availability, the rate at which viruses encounter a heterotrophic prokaryote cell (e.g., assumed to be proportional to VPR), and the subpopulation most likely to encounter (e.g., HNA:LNA) were also important in regulating viral dynamics. Rates of viral production can be affected by host physiology, either through host growth rate or prophage induction [76-78], however, specific prokaryote growth rate did not appear to significantly influence the variability in the abundance or activity within our viral community. Instead, lytic virus production was inversely associated with the fraction of HNA cells in the community, and was uncoupled from viral abundance. Data from several studies suggest a link between HNA cells and the dominate (both in terms of abundance and contributions to total lytic production) virus group in the present study-V1 $[30,79,80]$. This inverse relationship between lytic virus production and the fraction of HNA cells in the community may, therefore, reflect predator-prey oscillations in virus production with the density of active hosts.

The prevalence of the different viral replication modes (i.e., lytic versus lysogenic) can be related to the trophic status of a system [81-83]. In the DCM, prophage induction decreased hyperbolically with latitude in a manner consistent with increases in nutrient and $\mathrm{Chl} a$ concentrations (Pearson correlation to $\mathrm{PO}_{4}: \mathrm{r}=-0.82, p$-value $=0.01$ and $\mathrm{Chl} a: \mathrm{r}=-0.72, p$-value $=0.04$ ). This suggests that trophic status was likely an important factor modulating lysogeny in our bacteriophage the community in the DCM [76,77]. Conversely, prophage induction was absent or low in the surface ML of the subtropical region (south of $38^{\circ} n$ ), with the highest frequency of occurrence in the transition zone $\left(38-46^{\circ} n\right)$ between the strongly stratified oligotrophic region and the less stratified northern region. One possible explanation is that prolonged stratification in the subtropical region may have subjected hosts to high levels of solar radiation (particularly UV), which can act as an inducing agent and reduce the yield of viral production from Mitomycin C treatment $[84,85]$. Overall, prophage induction appeared to be strongly tied to low VPR, indicated that the rate at which viruses encountered a heterotrophic prokaryote cell was the primary factor governing lysogeny. This aligns well with the theory that the lysogeny represents a survival strategy of viruses to endure periods of low host abundance or production $[81,86]$.

\subsection{Controls on Grazing Mortality}

The densities of heterotrophic prokaryotes and HNF are thought to be strongly related to the degree of eutrophication with a predictable numerical relationship of prokaryotic to HNF abundances (HPA:HNF) among oligotrophic and eutrophic systems [87,88]. Indeed, HNF increased in proportion to the prokaryotic abundance with HPA:HNF averaging $1.1 \pm 0.8 \times 10^{3}$ in the subtropical region $\left(<48^{\circ} n\right)$ 
and increasing to $1.7 \pm 1.2 \times 10^{3}$ in the less stratified northern region. Temperature and turbulence were the primary physicochemical factors regulating the variability in the abundance and activity of bacterivorous protozoans across our latitudinal gradient. Temperature $[33,89]$ and turbulence $[34,35]$ have both been shown to have a positive effect on growth and grazing rates of bactivorous protists.

Heterotrophic nanoflagellate abundance was decoupled from measured grazing rates (i.e., in a RDA plot correlations are reflected in the angles between lines, wherein a $90^{\circ}$ angle represents no correlation), and was inversely correlated to ammonium concentrations. This may indicate strong top-down control of protists [90,91] and subsequent regenerated nitrogen (particularly in the oligotrophic subtropical region [92,93]), and/or heterotrophic nanoflagellates were not responsible for the majority of the bactivory in our heterotrophic prokaryotes community [47,94]. In addition to flagellated protists, pelagic ciliates are an important source of bacterial mortality [95]. However, the growth and feeding activity of ciliates are more sensitive to turbulence than their flagellate counterparts and have been shown to be negatively affected by increase in turbulence [35,36]. In order to better understand the decoupling of HNF and grazing rates (absence of a strong Lotka-Volterra predatory-prey relationship in between HNA:LNA and HNF), we applied the qualitative model proposed by Gasol [96], which provides a framework for evaluating the strength of top-down and bottom-up factors controlling HNF. All of our data fall well below the mean realized abundance (MRA) line supporting the theory that decoupling was due to strong top-down control of HNF (Figure S1).

Bacterivorous protozoa are thought to preferentially select for the actively growing cells of the bacterial assemblage by size-selectively grazing larger and more active cells in the community $[24,97]$. Our results indicate that grazing rate and HNF abundance increased with fraction of the HNA cells in the heterotrophic prokaryote community, supporting evidence that physiological and ecological differences in LNA and HNA cells may impact marine food webs by protozoans selectively grazing on HNA cells $[9,98]$. In addition, $K_{\mathrm{T}}$ values were also strongly related to HNA:LNA, suggesting that stratification may have also influenced the availability of prey type.

\subsection{Ecosystem Dynamics}

Our results reveal strong bottom-up control (resource availability) of heterotrophic prokaryote activity and as such variations in phytoplankton carbon (driven by vertical stratification) has direct consequences for the abundance and activity of the heterotrophic prokaryote community. The production and availability of DOM can vary across phytoplankton species, their growth phase, as well as the type of nutrients that limit growth [99-101], all of which are likely influenced by vertical stratification. The significant relationship between prokaryotic HNA:LNA and the phytoplankton viral lysis to grazing ratio implies that viral activity within the surrounding phytoplankton community provided HNA a (likely transient) opportunity to outcompete LNA cells which typically prevail under more oligotrophic conditions $[7,8]$. These results support evidence that organic matter released from algal cells by viral lysis not only provides substrate for surrounding heterotrophic prokaryotes, but is important in structuring community composition [20,67]. HNA:LNA was an important factor regulating the mortality of heterotrophic prokaryotes and thus the impact of these alterations likely propagated throughout the ecosystem.

In order to disentangle the role of viruses and heterotrophic nanoflagellates in controlling heterotrophic prokaryote communities we compared covariations in the abundances of these two mortality agents in the ML and MID sample depth (Figure S2). Viral abundance (Pearson $r=0.84$, $n=16, p$-value $\left.=1.9 \times 10^{-8}\right)$ and lytic virus production $(r=0.46, n=16, p$-value $=0.02)$ were positively associated with HNF in the ML. However, no connection was found between grazing rates and viral abundance, prokaryotic abundance, or virus mediated mortality. In the MID we found an opposite effect of HNF on viral abundance $(r=-0.39, n=12, p$-value $=0.09)$ and lytic virus production $(r=-0.57, n=8, p$-value $=0.04)$, supporting evidence that the presence of HNF can reduce viral activity $[80,83]$. As viruses and HNF compete for the same resource (i.e., prey/host), exploitative competition is expected, that is, the activity of one reduces the resource and thereby the activity of the 
other (Figure S2c). In addition to competition, HNF may also reduce the abundance and production of viruses by direct feeding, grazing on infection sensitive hosts (favoring species less susceptible to viral infection; [102]), or by predation on infected cells. Direct predation on viruses by HNF occurs at much lower rates compared heterotrophic prokaryote prey $(4 \%)$, resulting in negligible contributions to the removal of viruses (around $0.1 \%$ of the virus community $\mathrm{h}^{-1}$ ) $[103,104]$.

Overall, viral-mediate morality was the primary top-down process regulating the heterotrophic prokaryotic communities in the current study, which may be attributed to the strong top down regulation of HNF [105,106]. Viruses were responsible for an average of $55 \pm 22 \%$ (ranging from 12 to $100 \%$, median 60.3 ) of the total mortality occurring within the heterotrophic prokaryote communities. This agrees well with the literature that generally attributes $10-50 \%$ of the total bacterial mortality in the surface ocean to viruses [102,107]. In terms of carbon flux, our data suggest that around 39\% of the total available carbon (i.e., standing stock + production) of our prokaryote communities was cycled back into the water column by viral activity compared to $26 \%$ entering the food web by grazing. Moreover, the ratio of total mortality and available prokaryote carbon reveals that over the latitudinal gradient in stratification the heterotrophic prokaryote community gradually moves from a near steady state system regulated by high turnover in subtropical region to net heterotrophic production in the temperate region. This supports evidence that loss within heterotrophic prokaryotic communities expressed as a fraction of either biomass or production tends to be negatively associated with ecosystem productivity [108-112].

Supplementary Materials: The following are available online at http://www.mdpi.com/1999-4915/12/11/1293/s1, Figure S1: evaluating the strength of top-down and bottom-up factors controlling HNF, Figure S2: interactions of between viruses and heterotrophic nanoflagellates. Table S1: physicochemical data used for multivariate analysis.

Author Contributions: C.P.D.B. conceived and designed the project. K.D.A.M. conducted experiments, measured samples, analyzed data, and drafted the manuscript. C.P.D.B. advised on analysis, and revised and edited the manuscript. All authors have read and agreed to the published version of the manuscript.

Funding: The STRATIPHYT project was supported by the division for Earth and Life Sciences Foundation (ALW), with financial aid from the Netherlands Organization for Scientific Research (NWO), grant number 839.08.420. K.D.A. Mojica also received partial funding under the NASA-NAAMES; grant NNX15AF30G.

Acknowledgments: We thank the captains and shipboard crews of R/V Pelagia and scientific crews during the cruises, with special thanks to Tea de Vries. We acknowledge the support of NIOZ Marine Research Facilities (MRF) on-shore and on-board.

Conflicts of Interest: The authors declare no conflict of interest. The funders had no role in the design of the study; in the collection, analyses, or interpretation of data; in the writing of the manuscript, or in the decision to publish the results.

\section{References}

1. Zubkov, M.V.; Fuchs, B.M.; Burkill, P.H.; Amann, R. Comparison of Cellular and Biomass Specific Activities of Dominant Bacterioplankton Groups in Stratified Waters of the Celtic Sea. Appl. Environ. Microbiol. 2001, 67, 5210-5218. [CrossRef] [PubMed]

2. Gasol,J.M.; Del Giorgio, P.A. Using flow cytometry for counting natural planktonic bacteria and understanding the structure of planktonic bacterial communities. Sci. Mar. 2000, 64, 197-224. [CrossRef]

3. Button, D.K.; Robertson, B.R. Determination of DNA Content of Aquatic Bacteria by Flow Cytometry. Appl. Environ. Microbiol. 2001, 67, 1636-1645. [CrossRef] [PubMed]

4. Bouvier, T.; Del Giorgio, P.A.; Gasol, J.M. A comparative study of the cytometric characteristics of High and Low nucleic-acid bacterioplankton cells from different aquatic ecosystems. Environ. Microbiol. 2007, 9, 2050-2066. [CrossRef]

5. Proctor, C.R.; Besmer, M.D.; Langenegger, T.; Beck, K.; Walser, J.-C.; Ackermann, M.; Bürgmann, H.; Hammes, F. Phylogenetic clustering of small low nucleic acid-content bacteria across diverse freshwater ecosystems. ISME J. 2018, 12, 1344-1359. [CrossRef]

6. Van Wambeke, F.; Català, P.; Pujo-Pay, M.; LeBaron, P. Vertical and longitudinal gradients in HNA-LNA cell abundances and cytometric characteristics in the Mediterranean Sea. Biogeosciences 2011, 8, 1853-1863. [CrossRef] 
7. Nishimura, Y.; Kim, C.; Nagata, T. Vertical and Seasonal Variations of Bacterioplankton Subgroups with Different Nucleic Acid Contents: Possible Regulation by Phosphorus. Appl. Environ. Microbiol. 2005, 71, 5828-5836. [CrossRef]

8. Andrade, L.; Gonzalez, A.M.; Rezende, C.E.; Suzuki, M.; Valentin, J.L.; Paranhos, R. Distribution of HNA and LNA bacterial groups in the Southwest Atlantic Ocean. Braz. J. Microbiol. 2007, 38, 330-336. [CrossRef]

9. Gasol,J.M.; Zweifel, U.L.; Peters, F.; Fuhrman, J.A.; Hagström, A. Significance of Size and Nucleic Acid Content Heterogeneity as Measured by Flow Cytometry in Natural Planktonic Bacteria. Appl. Environ. Microbiol. 1999, 65, 4475-4483. [CrossRef]

10. LeBaron, P.; Servais, P.; Agogué, H.; Courties, C.; Joux, F. Does the High Nucleic Acid Content of Individual Bacterial Cells Allow Us To Discriminate between Active Cells and Inactive Cells in Aquatic Systems? Appl. Environ. Microbiol. 2001, 67, 1775-1782. [CrossRef]

11. LeBaron, P.; Servais, P.; Baudoux, A.C.; Bourrain, M.; Courties, C.; Parthuisot, N. Variations of bacterial-specific activity with cell size and nucleic acid content assessed by flow cytometry. Aquat. Microb. Ecol. 2002, 28, 131-140. [CrossRef]

12. Longnecker, K.; Sherr, B.F.; Sherr, E.B. Activity and Phylogenetic Diversity of Bacterial Cells with High and Low Nucleic Acid Content and Electron Transport System Activity in an Upwelling Ecosystem. Appl. Environ. Microbiol. 2005, 71, 7737-7749. [CrossRef] [PubMed]

13. Jochem, F.J.; Lavrentyev, P.J.; First, M.R. Growth and grazing rates of bacteria groups with different apparent DNA content in the Gulf of Mexico. Mar. Biol. 2004, 145, 1213-1225. [CrossRef]

14. Duarte, C.M.; Agustí, S.; Vaqué, D.; Agawin, N.S.R.; Felipe, J.; Casamayor, E.O.; Gasol, J.M. Experimental test of bacteria-phytoplankton coupling in the Southern Ocean. Limnol. Oceanogr. 2005, 50, 1844-1854. [CrossRef]

15. Pernthaler, J. Predation on prokaryotes in the water column and its ecological implications. Nat. Rev. Microbiol. 2005, 3, 537-546. [CrossRef] [PubMed]

16. Weinbauer, M.G.; Rassoulzadegan, F. Are viruses driving microbial diversification and diversity? Environ. Microbiol. 2004, 6, 1-11. [CrossRef]

17. Wilhelm, S.W.; Suttle, C.A. Viruses and nutrient cycles in the sea-Viruses play critical roles in the structure and function of aquatic food webs. Bioscience 1999, 49, 781-788. [CrossRef]

18. Fuhrman, J.A.; Noble, R.T. Viruses and protists cause similar bacterial mortality in coastal seawater. Limnol. Oceanogr. 1995, 40, 1236-1242. [CrossRef]

19. Middelboe, M.; Jørgensen, N.O.G. Viral lysis of bacteria: An important source of dissolved amino acids and cell wall compounds. J. Mar. Biol. Assoc. U. K. 2006, 86, 605-612. [CrossRef]

20. Sheik, A.R.; Brussaard, C.P.D.; Lavik, G.; Lam, P.; Musat, N.; Krupke, A.; Littmann, S.; Strous, M.; Kuypers, M.M.M. Responses of the coastal bacterial community to viral infection of the algae Phaeocystis globosa. ISME J. 2014, 8, 212-225. [CrossRef] [PubMed]

21. Lønborg, C.; Middelboe, M.; Brussaard, C.P.D. Viral lysis of Micromonas pusilla: Impacts on dissolved organic matter production and composition. Biogeochemistry 2013, 116, 231-240. [CrossRef]

22. Hahn, M.W.; Hofle, M.G. Grazing of protozoa and its effect on populations of aquatic bacteria. FEMS Microbiol. Ecol. 2001, 35, 113-121. [CrossRef]

23. Hahn, M.W.; Hofle, M.G. Predation as a shaping force for the phenotypic and genotypic composition of planktonic bacteria. Antonie Van Leeuwenhoek 2002, 81, 413-434. [CrossRef]

24. Gonzalez, J.M.; Sherr, E.B.; Sherr, B.F. Size-selective grazing on bacteria by natural assemblages of estuarine flagellates and ciliates. Appl. Environ. Microbiol. 1990, 56, 583-589. [CrossRef] [PubMed]

25. Thingstad, T.F. Elements of a theory for the mechanisms controlling abundance, diversity, and biogeochemical role of lytic bacterial viruses in aquatic systems. Limnol. Oceanogr. 2000, 45, 1320-1328. [CrossRef]

26. Winter, C.; Smit, A.; Herndl, G.J.; Weinbauer, M.G. Impact of Virioplankton on Archaeal and Bacterial Community Richness as Assessed in Seawater Batch Cultures. Appl. Environ. Microbiol. 2004, 70, 804-813. [CrossRef] [PubMed]

27. Gasol, J.M.; Del Giorgio, P.A.; Massana, R.; Duarte, C.M. Active versus inactive bacteria:size-dependence in a coastal marine plankton community. Mar. Ecol. Prog. Ser. 1995, 128, 91-97. [CrossRef]

28. Jürgens, K.; Güde, H. The potential importance of grazing-resistant bacteria in planktonic systems. Mar. Ecol. Prog. Ser. 1994, 112, 169-188. [CrossRef]

29. Bouvier, T.; Maurice, C.F. A Single-Cell Analysis of Virioplankton Adsorption, Infection, and Intracellular Abundance in Different Bacterioplankton Physiologic Categories. Microb. Ecol. 2011, 62, 669-678. [CrossRef] 
30. Mojica, K.D.A.; Carlson, C.A.; Behrenfeld, M.J. Regulation of Low and High Nucleic Acid Fluorescent Heterotrophic Prokaryote Subpopulations and Links to Viral-Induced Mortality within Natural Prokaryote-Virus Communities. Microb. Ecol. 2020, 79, 213-230. [CrossRef]

31. Mojica, K.D.A.; Van De Poll, W.H.; Kehoe, M.; Huisman, J.; Timmermans, K.R.; Buma, A.G.J.; Van Der Woerd, H.J.; Hahn-Woernle, L.; Dijkstra, H.A.; Brussaard, C.P.D. Phytoplankton community structure in relation to vertical stratification along a north-south gradient in the Northeast Atlantic Ocean. Limnol. Oceanogr. 2015, 60, 1498-1521. [CrossRef]

32. Sherr, B.F.; Sherr, E.B.; Rassoulzadegan, F. Rates of Digestion of Bacteria by Marine Phagotrophic Protozoa: Temperature Dependence. Appl. Environ. Microbiol. 1988, 54, 1091-1095. [CrossRef] [PubMed]

33. Rose, J.M.; Vora, N.M.; Countway, P.D.; Gast, R.J.; Caron, D.A. Effects of temperature on growth rate and gross growth efficiency of an Antarctic bacterivorous protist. ISME J. 2009, 3, 252-260. [CrossRef] [PubMed]

34. Delaney, M.P. Effects of Temperature and Turbulence on the Predator-Prey Interactions between a Heterotrophic Flagellate and a Marine Bacterium. Microb. Ecol. 2003, 45, 218-225. [CrossRef]

35. Shimeta, J.; Jumars, P.A.; Lessard, E.J. Influences of turbulence on suspension feeding by planktonic protozoa; experiments in laminar shear fields. Limnol. Oceanogr. 1995, 40, 845-859. [CrossRef]

36. Dolan, J.R.; Sall, N.; Metcalfe, A.; Gasser, B. Effects of turbulence on the feeding and growth of a marine oligotrich ciliate. Aquat. Microb. Ecol. 2003, 31, 183-192. [CrossRef]

37. Jurado, E.; Van Der Woerd, H.J.; Dijkstra, H.A. Microstructure measurements along a quasi-meridional transect in the northeastern Atlantic Ocean. J. Geophys. Res. 2012, 117, C04016. [CrossRef]

38. Van De Poll, W.H.; Kulk, G.; Timmermans, K.R.; Brussaard, C.P.D.; Van Der Woerd, H.J.; Kehoe, M.J.; Mojica, K.D.A.; Visser, R.J.W.; Rozema, P.D.; Buma, A.G.J. Phytoplankton chlorophyll a biomass, composition, and productivity along a temperature and stratification gradient in the northeast Atlantic Ocean. Biogeosciences 2013, 10, 4227-4240. [CrossRef]

39. Marie, D.; Brussaard, C.P.D.; Thyrhaug, R.; Bratbak, G.; Vaulot, D. Enumeration of Marine Viruses in Culture and Natural Samples by Flow Cytometry. Appl. Environ. Microbiol. 1999, 65, 45-52. [CrossRef]

40. Mojica, K.D.A.; Evans, C.; Brussaard, C.P.D. Flow cytometric enumeration of marine viral populations at low abundances. Aquat. Microb. Ecol. 2014, 71, 203-209. [CrossRef]

41. Vaulot, D. CYTOPC: Processing software for flow cytometric data. Signal Noise 1989, 2, 8.

42. Mojica, K.D.A.; Huisman, J.; Wilhelm, S.W.; Brussaard, C.P.D. Latitudinal variation in virus-induced mortality of phytoplankton across the North Atlantic Ocean. ISME J. 2016, 10, 500-513. [CrossRef] [PubMed]

43. Simon, M.; Azam, F. Protein content and protein synthesis rates of planktonic marine bacteria. Mar. Ecol. Prog. Ser. 1989, 51, 201-213. [CrossRef]

44. Fukuda, R.; Ogawa, H.; Nagata, T.; Koike, I. Direct Determination of Carbon and Nitrogen Contents of Natural Bacterial Assemblages in Marine Environments. Appl. Environ. Microbiol. 1998, 64, 3352-3358. [CrossRef] [PubMed]

45. Winget, D.M.; Williamson, K.E.; Helton, R.R.; Wommack, K.E. Tangential flow diafiltration: An improved technique for estimation of virioplankton production. Aquat. Microb. Ecol. 2005, 41, 221-232. [CrossRef]

46. Parada, V.; Herndl, G.J.; Weinbauer, M.G. Viral burst size of heterotrophic prokaryotes in aquatic systems. J. Mar. Biol. Assoc. U. K. 2006, 86, 613-621. [CrossRef]

47. Sherr, B.F.; Sherr, E.B.; Fallon, R.D. Use of Monodispersed, Fluorescently Labeled Bacteria to Estimate In Situ Protozoan Bacterivory t. Appl. Environ. Microbiol. 1987, 53, 958-965. [CrossRef]

48. R Core Team. R: A Language and Environment for Statistical Computing; R Foundation for Statistical Computing: Vienna, Austria, 2018.

49. Oksanen, J.; Blanchet, F.G.; Kindt, R.; Legendre, P.; Minchin, P.R.; O’Hara, R.B.; Simpson, G.L.; Solymos, P.; Stevens, M.H.H.; Wagner, H. Vegan: Community Ecology Package, R Package Version 2.5-6. 2019. Available online: https://cran.r-project.org/web/packages/vegan/index.html (accessed on 12 November 2020).

50. Zuur, A.F.; Ieno, E.N.; Elphick, C.S. A protocol for data exploration to avoid common statistical problems. Methods Ecol. Evol. 2010, 1, 3-14. [CrossRef]

51. Zuur, A.; Ieno, E.N.; Walker, N.; Saveliev, A.A.; Smith, G.M. Mixed Effects Models and Extensions in Ecology with R; Springer: New York, NY, USA, 2009.

52. Polovina, J.J.; Howell, E.A.; Abecassis, M. Ocean's least productive waters are expanding. Geophys. Res. Lett. 2008, 35, L03618. [CrossRef]

53. Longhurst, A.R. Ecological Geography of the Sea; Academic Press: London, UK, 2007. 
54. Cole, J.J.; Findlay, S.; Pace, M.L. Bacterial production in fresh and saltwater ecosystems: A cross-system overview. Mar. Ecol. Prog. Ser. 1988, 43, 1-10. [CrossRef]

55. White, P.A.; Kalff, J.; Rasmussen, J.B.; Gasol, J.M. The effect of temperature and algal biomass on bacterial production and specific growth rate in freshwater and marine habitats. Microb. Ecol. 1991, 21, 99-118. [CrossRef] [PubMed]

56. Gasol, J.M.; Duarte, C.M. Comparative analyses in aquatic microbial ecology: How far do they go? FEMS Microbiol. Ecol. 2000, 31, 99-106. [CrossRef] [PubMed]

57. Church, M.J.; Hutchins, D.A.; Ducklow, H.W. Limitation of Bacterial Growth by Dissolved Organic Matter and Iron in the Southern Ocean. Appl. Environ. Microbiol. 2000, 66, 455-466. [CrossRef] [PubMed]

58. Carlson, C.A.; Ducklow, H.W. Growth of bacterioplankton and consumption of dissolved organic carbon in the Sargasso Sea. Aquat. Microb. Ecol. 1996, 10, 69-85. [CrossRef]

59. Kirchman, D.L. Limitation of bacterial growth by dissolved organic matter in the subarctic Pacific. Mar. Ecol. Prog. Ser. 1990, 62, 47-54. [CrossRef]

60. Servais, P.; Casamayor, E.O.; Courties, C.; Catala, P.; Parthuisot, N.; LeBaron, P. Activity and diversity of bacterial cells with high and low nucleic acid content. Aquat. Microb. Ecol. 2003, 33, 41-51. [CrossRef]

61. Longnecker, K.; Sherr, B.F.; Sherr, E.B. Variation in cell-specific rates of leucine and thymidine incorporation by marine bacteria with high and with low nucleic acid content off the Oregon coast. Aquat. Microb. Ecol. 2006, 43, 113-125. [CrossRef]

62. Talarmin, A.; Van Wambeke, F.; Català, P.; Courties, C.; LeBaron, P. Flow cytometric assessment of specific leucine incorporation in the open Mediterranean. Biogeosciences 2011, 8, 253-265. [CrossRef]

63. Bowman, J.S.; Amaral-Zettler, L.A.; Rich, J.J.; Luria, C.M.; Ducklow, H.W. Bacterial community segmentation facilitates the prediction of ecosystem function along the coast of the western Antarctic Peninsula. ISME J. 2017, 11, 1460-1471. [CrossRef]

64. Al-Otaibi, N.; Huete-Stauffer, T.M.; Calleja, M.L.; Irigoien, X.; Morán, X.A.G. Seasonal variability and vertical distribution of autotrophic and heterotrophic picoplankton in the Central Red Sea. PeerJ 2020, 8, e8612. [CrossRef]

65. Kujawinski, E.B.; Longnecker, K.; Barott, K.L.; Weber, R.J.M.; Soule, M.C.K. Microbial Community Structure Affects Marine Dissolved Organic Matter Composition. Front. Mar. Sci. 2016, 3, 3. [CrossRef]

66. Strom, S.L.; Benner, R.; Ziegler, S.; Dagg, M.J. Planktonic grazers are a potentially important source of marine dissolved organic carbon. Limnol. Oceanogr. 1997, 42, 1364-1374. [CrossRef]

67. Brussaard, C.P.D.; Mari, X.; Van Bleijswijk, J.D.L.; Veldhuis, M.J.W. A mesocosm study of Phaeocystis globosa (Prymnesiophyceae) population dynamics II. Significance for the microbial community. Harmful Algae 2005, 4, 875-893. [CrossRef]

68. Schattenhofer, M.; Wulf, J.; Kostadinov, I.; Glöckner, F.O.; Zubkov, M.V.; Fuchs, B.M. Phylogenetic characterisation of picoplanktonic populations with high and low nucleic acid content in the North Atlantic Ocean. Syst. Appl. Microbiol. 2011, 34, 470-475. [CrossRef] [PubMed]

69. Spring, S.; Scheuner, C.; Goker, M.; Klenk, H.P. A taxonomic framework for emerging groups of ecologically important marine gammaproteobacteria based on the reconstruction of evolutionary relationships using genome-scale data. Front. Microbiol. 2015, 6, 281. [CrossRef]

70. Liu, S.; Liu, Z. Distinct capabilities of different Gammaproteobacterial strains on utilizing small peptides in seawater. Sci. Rep. 2020, 10, 1-11. [CrossRef]

71. Cottrell, M.T.; Kirchman, D.L. Natural Assemblages of Marine Proteobacteria and Members of the Cytophaga-Flavobacter Cluster Consuming Low- and High-Molecular-Weight Dissolved Organic Matter. Appl. Environ. Microbiol. 2000, 66, 1692-1697. [CrossRef]

72. Moran, X.A.G.; Alonso-Saez, L.; Nogueira, E.; Ducklow, H.W.; Gonzalez, N.; Lopez-Urrutia, A.; Diaz-Perez, L.; Calvo-Diaz, A.; Arandia-Gorostidi, N.; Huete-Stauffer, T.M. More, smaller bacteria in response to ocean's warming? Proc. R. Soc. B Biol. Sci. 2015, 282, 20150371. [CrossRef]

73. De Corte, D.; Sintes, E.; Winter, C.; Yokokawa, T.; Reinthaler, T.; Herndl, G.J. Links between viral and prokaryotic communities throughout the water column in the (sub)tropical Atlantic Ocean. ISME J. 2010, 4, 1431-1442. [CrossRef]

74. De Corte, D.; Sintes, E.; Yokokawa, T.; Reinthaler, T.; Herndl, G.J. Links between viruses and prokaryotes throughout the water column along a North Atlantic latitudinal transect. ISME J. 2012, 6, 1566-1577. [CrossRef] 
75. Lara, E.; Vaqué, D.; Sà, E.L.; Boras, J.A.; Gomes, A.; Borrull, E.; Díez-Vives, C.; Teira, E.; Pernice, M.C.; Garcia, F.C.; et al. Unveiling the role and life strategies of viruses from the surface to the dark ocean. Sci. Adv. 2017, 3, e1602565. [CrossRef] [PubMed]

76. Williamson, S.J.; Houchin, L.A.; McDaniel, L.; Paul, J.H. Seasonal Variation in Lysogeny as Depicted by Prophage Induction in Tampa Bay, Florida. Appl. Environ. Microbiol. 2002, 68, 4307-4314. [CrossRef] [PubMed]

77. Motegi, C.; Nagata, T. Enhancement of viral production by addition of nitrogen or nitrogen plus carbon in subtropical surface waters of the South Pacific. Aquat. Microb. Ecol. 2007, 48, 27-34. [CrossRef]

78. Middelboe, M. Bacterial Growth Rate and Marine Virus-Host Dynamics. Microb. Ecol. 2000, 40, 114-124. [CrossRef]

79. Evans, C.; Brandsma, J.; Pond, D.W.; Venables, H.J.; Meredith, M.P.; Witte, H.J.; Stammerjohn, S.; Wilson, W.H.; Clarke, A.; Brussaard, C.P.D. Drivers of interannual variability in virioplankton abundance at the coastal western Antarctic peninsula and the potential effects of climate change. Environ. Microbiol. 2017, 19, 740-755. [CrossRef]

80. Sabbagh, E.I.; Huete-Stauffer, T.M.; Calleja, M.L.L.; Silva, L.; Viegas, M.; Morán, X.A.G. Weekly variations of viruses and heterotrophic nanoflagellates and their potential impact on bacterioplankton in shallow waters of the central Red Sea. FEMS Microbiol. Ecol. 2020, 96. [CrossRef]

81. Payet, J.P.; Suttle, C.A. To kill or not to kill: The balance between lytic and lysogenic viral infection is driven by trophic status. Limnol. Oceanogr. 2013, 58, 465-474. [CrossRef]

82. Weinbauer, M.G.; Brettar, I.; Höfle, M.G. Lysogeny and virus-induced mortality of bacterioplankton in surface, deep, and anoxic marine waters. Limnol. Oceanogr. 2003, 48, 1457-1465. [CrossRef]

83. Bongiorni, L.; Magagnini, M.; Armeni, M.; Noble, R.; Danovaro, R. Viral Production, Decay Rates, and Life Strategies along a Trophic Gradient in the North Adriatic Sea. Appl. Environ. Microbiol. 2005, 71, 6644-6650. [CrossRef]

84. Weinbauer, M.G.; Suttle, C.A. Lysogeny and prophage induction in coastal and offshore bacterial communities. Aquat. Microb. Ecol. 1999, 18, 217-225. [CrossRef]

85. Wilcox, R.M.; Fuhrman, J.A. Bacterial viruses in coastal seawater: Lytic rather than lysogenic production. Mar. Ecol. Prog. Ser. 1994, 114, 35-45. [CrossRef]

86. Mojica, K.D.A.; Brussaard, C.P.D. Factors affecting virus dynamics and microbial host-virus interactions in marine environments. FEMS Microbiol. Ecol. 2014, 89, 495-515. [CrossRef] [PubMed]

87. Sanders, R.W.; Caron, D.A.; Berninger, U.-G. Relationships between bacteria and heterotrophic nanoplankton in marine and fresh waters: An inter-ecosystem comparison. Mar. Ecol. Prog. Ser. 1992, 86, 1-14. [CrossRef]

88. Krstulovic, N.; Solic, M.; Marasovic, I. Relationship between bacteria, phytoplankton, and heterotrophic nanoflagellates along a trophic gradient. Helgolaender Meeresunters. 1998, 51, 433-443. [CrossRef]

89. Tsai, A.Y.; Gong, G.-C.; Shiau, W. Viral lysis and nanoflagellate grazing on prokaryotes: Effects of short-term warming in a coastal subtropical marine system. Hydrobiologia 2015, 751, 43-54. [CrossRef]

90. Sandaa, R.-A.; Pree, B.; Larsen, A.; Våge, S.; Töpper, B.; Töpper, J.P.; Thyrhaug, R.; Thingstad, T.F. The Response of Heterotrophic Prokaryote and Viral Communities to Labile Organic Carbon Inputs Is Controlled by the Predator Food Chain Structure. Viruses 2017, 9, 238. [CrossRef]

91. Larsen, A.; Egge, J.K.; Nejstgaard, J.C.; Di Capua, I.; Thyrhaug, R.; Bratbak, G.; Thingstad, T.F. Contrasting response to nutrient manipulation in A rctic mesocosms are reproduced by a minimum microbial food web model. Limnol. Oceanogr. 2015, 60, 360-374. [CrossRef]

92. Sherr, B.F.; Sherr, E.B.; Berman, T. Grazing, Growth, and Ammonium Excretion Rates of a Heterotrophic Microflagellate Fed with Four Species of Bacteria. Appl. Environ. Microbiol. 1983, 45, 1196-1201. [CrossRef]

93. Dolan, J.R. Phosphorus and ammonia excretion by planktonic protists. Mar. Geol. 1997, 139, $109-122$. [CrossRef]

94. Vaqué, D.; Pace, M.L.; Findlay, S.E.G.; Lints, D. Fate of bacterial production in a heterotrophic ecosystem: Grazing by protists and metazoans in the Hudson Estuary. Mar. Ecol. Prog. Ser. 1992, 89, 155-163. [CrossRef]

95. Sherr, E.B.; Sherr, B.F. High rates of consumption of bacteria by pelagic ciliates. Nature 1987, 325, 710-711. [CrossRef]

96. Gasol, J.M. A framework for the assessment of top-down vs. bottom-up control of heterotrophic nanoflagellate abundance. Mar. Ecol. Prog. Ser. 1994, 113, 291-300. [CrossRef] 
97. Koton-Czarnecka, M.; Chróst, R.J. Protozoans prefer large and metabolically active bacteria. Pol. J. Environ. Stud. 2003, 12, 325-334.

98. Sintes, E.; Del Giorgio, P.A. Feedbacks between protistan single-cell activity and bacterial physiological structure reinforce the predator/prey link in microbial foodwebs. Front. Microbiol. 2014, 5, 453. [CrossRef] [PubMed]

99. Wear, E.K.; Carlson, C.A.; Windecker, L.A.; Brzezinski, M.A. Roles of diatom nutrient stress and species identity in determining the short- and long-term bioavailability of diatom exudates to bacterioplankton. Mar. Chem. 2015, 177, 335-348. [CrossRef]

100. López-Sandoval, D.C.; Rodríguez-Ramos, T.; Cermeño, P.; Marañón, E. Exudation of organic carbon by marine phytoplankton: Dependence on taxon and cell size. Mar. Ecol. Prog. Ser. 2013, 477, 53-60. [CrossRef]

101. Obernosterer, I.; Herndl, G.J. Phytoplankton extracellular release and bacterial growth: Dependence on the inorganic n: P ratio. Mar. Ecol. Prog. Ser. 1995, 116, 247-257. [CrossRef]

102. Fuhrman, J.A. Marine viruses and their biogeochemical and ecological effects. Nature 1999, 399, 541-548. [CrossRef]

103. Suttle, C.A.; Chen, F. Mechanisms and Rates of Decay of Marine Viruses in Seawater. Appl. Environ. Microbiol. 1992, 58, 3721-3729. [CrossRef]

104. Gonzalez, J.M.; Suttle, C.A. Grazing by marine nanoflagellates on viruses and virus-sized particles: Ingestion and digestion. Mar. Ecol. Prog. Ser. 1993, 94, 1-10. [CrossRef]

105. Tsai, A.Y.; Gong, G.C.; Hung, J. Seasonal variations of viral- and nanoflagellate-mediated mortality of heterotrophic bacteria in the coastal ecosystem of subtropical Western Pacific. Biogeosci. Discuss. 2012, 9, 17235-17261. [CrossRef]

106. Weinbauer, M.G.; Peduzzi, P. Significance of viruses versus heterotrophic nanoflagellates for controlling bacterial abundance in the Northern Adriatic Sea. J. Plankton. Res. 1995, 17, 1851-1856. [CrossRef]

107. Wommack, K.E.; Colwell, R.R. Virioplankton: Viruses in Aquatic Ecosystems. Microbiol. Mol. Biol. Rev. 2000, 64, 69-114. [CrossRef] [PubMed]

108. Vaqué, D.; Alonso-Sáez, L.; Arístegui, J.; Agustí, S.; Duarte, C.M.; Sala, M.M.; Vázquez-Domínguez, E.; Gasol, J.M. Bacterial production and losses to predators along an open ocean productivity gradient in the Subtropical North East Atlantic Ocean. J. Plankton Res. 2014, 36, 198-213. [CrossRef]

109. Cuevas, L.A.; Daneri, G.; Jacob, B.; Montero, P. Microbial abundance and activity in the seasonal upwelling area off Concepción ( $\left.36^{\circ} \mathrm{S}\right)$, central Chili: A comparison of upwelling and non-upwelling conditions. Deep-Sea Res. II 2004, 51, 2427-2440. [CrossRef]

110. Gasol, J.M.; Pedrós-Alió, C.; Vaqué, D. Regulation of bacterial assemblages in oligotrophic plankton systems: Results from experimental and empirical approaches. Antonie Van Leeuwenhoek 2002, 81, 435-452. [CrossRef]

111. Paterson, J.S.; Nayar, S.; Mitchell, J.G.; Seuront, L. A local upwelling controls viral and microbial community structure in South Australian continental shelf waters. Estuar. Coast. Shelf Sci. 2012, 96, 197-208. [CrossRef]

112. Boras, J.A.; Sala, M.M.; Baltar, F.; Aristegui, J.; Duarte, C.M.; Vaque, D. Effect of viruses and protists on bacteria in eddies of the Canary Current region (subtropical northeast Atlantic). Limnol. Oceanogr. 2010, 55, 885-898. [CrossRef]

Publisher's Note: MDPI stays neutral with regard to jurisdictional claims in published maps and institutional affiliations.

(C) 2020 by the authors. Licensee MDPI, Basel, Switzerland. This article is an open access article distributed under the terms and conditions of the Creative Commons Attribution (CC BY) license (http://creativecommons.org/licenses/by/4.0/). 